\title{
вывод
}

Настоящее дело дает возможность всем увидеть значение международных средств правовой зашиты, правильное использование которых в огромной степени зависит от опыта и связей в юридическом мире, от плодотворных отношений с профессионалами из других стран, которые являются не просто источником клиентуры для юридических фирм в России, но и средством постоянной квалифицированной поддержки в делах последних за рубежом.

Ю.Э. Монастмрский, кандидат юридических наук партнер международной юридической фирмы "ММЦП \& $\mathrm{K}^{6}$ "

1 В российском праве такая ситуация именуется "переходом прав к другому лицу на основании закона" (статья 387 ГК РФ), однако, термин "суброгация" в данном случае также вполне применим: "Суброгация означает занятие третьим лицом, которое уплатило долг, места кредитора, которому оно его уплатило, так что оно может осуществлять против должника все права, которые кредитор, не получив платежа, мог бы предъявить" (Black's Law Dictionary. - St. Paul, Minn., West Group, Sixth edition, 1990, p. 1427).

2 Вестник Высшего Арбитражного Суда Российской Федерации, 1996, № 1.

Статья поступила в редакцию в июле 2000 года.

\section{ИСТОРИЯ ПРИВЕДЕНИЯ В ИСПОЛНЕНИЕ В РОССИИ ОДНОГО ИЗ РЕШЕНИЙ АРБИТРАЖНОГО ИНСТИТУТА ТОРГОВОЙ ПАЛАТЫ СТОКГОЛЬМА}

Отечественное регулирование вопросов признания и приведения в исполнение иностранных арбитражных решений насчитывает уже несколько десятков лет. Вместе с тем, серьезное его развитие началось только несколько лет назад. Соответственно, на этом пути российское право ожидает большое количество сложностей и проблем, разрешать которые призваны, в первую очередь, государственные суды.

В этой связи достаточно большой интерес вызывает история приведения в исполнение в России одного из решений Арбитражного Института Торговой Палаты Стокгольма (далее также именуемого “Арбитражный Суд”), демонстрирующая многие острые проблемы российского регулирования в этой сфере. Данная история демонстрнрует, с какими неожиданностями могут столкнуться в России попытки добиться признания и приведения иностранных арбитражных решений в исполнение, причем в ситуациях, на первый взгляд, достаточно простых. Более того, она является наглядным примером того, какие сложные юридические вопросы возникают при признании и приведении таких решений в исполнение. Наконец, эта история является уникальной еше и в том плане, что все без исключения юрисдикционыые органы, в ней участвовавшие, допустили достаточно серьезные правовые неточности. 
Международная юридическая фирма “ММЦП \& $\mathrm{K}^{\text {o" }}$ в личе одного из партнеров принимала участие в этом деле, и ей удалось внести существенный вклад в благоприятный исход спора для стороны - крупного российского внешнеэкономического объединения, - требовавшей приведения в исполнение в России решения Арбитражного Суда.

Следует отметить, что приводимое ниже описание такого приведения в исполнение в одном из своих аспектов уже являлось предметом анализа автора настоящей статьи '. Однако вся эта история является настолько интересной и поучительной, что ей еще раз следует уделить внимание, причем в отношении уже иных аспектов, и внимание более тщательное. Соответственно, далее будут рассматриваться вопросы, ранее автором в предшествующей его статье не анализировавшиеся (впрочем, это не исключает того, что те или иные моменты из последней будут повторены ниже еще раз).

\section{1. ОБСТОЯТЕЛЬСТВА ДЕЛА}

Решение Арбитражного Суда (в составе его членов была представлена и Росскя), о котором пойдет речь ниже, было вынесено по следуюшему делу: 24 июня 1992 г. российское юридическое лицо и шведская компания заключили на территории России договор, названный "кредитное соглашение", согласно которому российскому юридическому лицу был предоставлен заем в валюте Швеции. В связи с нарушением заемщиком своих обязательств шведская компания в соответствии с арбитражной оговоркой в кредитном соглашении обратилась в Арбитражный Суд.

Возражая против требований истца, ответчик, в частности, утверждал, что при заключении кредитного соглашения было нарушено обязательное для него Постановление Совета Министров СССР № 122 от 14 февраля 1978 г. "О порядке подписания внешнеторговых сделок" (далее также именуемое "Постановление 1978 г.") ${ }^{2}$. Данное Постановление устанавливало особую процедуру оформления внешнеторговых сделок, совершаемых "советскими организациями', в виде лодписания их всегда двумя лицами, занимающими определенные должности в соответствующей организации. Следует отметить, что согласно статье 45 Гражданского кодекса РСФСР 1964 г. (действовавшей до 1 января 1995 г.) несоблюдение этого предписания влекло недействительность внешнеторговой сделки. При этом по смыслу этого Гражданского кодекса такая сделка являлась не оспоримой, а ничтожной. Постановление 1978 г. неоднократно применялось на практике Внешнеторговой арбитражной комиссией при ТПП СССР, и соответствующие сделки признавались недействительными ${ }^{3}$.

Попутно следует отметить, что согласно российскому праву на территории России акты органов Союза ССР продолжают применяться, но только если их действие не приостановлено или если они не противоречат российскому законодательству, принятому позднее ${ }^{4}$.

Формально Постановление 1978 г. в России не приостанавливалось и не отменялось. Однако ввиду отказа в России от монополии внешней торговли еще в 1991-1992 гт. в российском праве на уровне доктрины, а также в практике Арбитражного суда (затем переименованного в "Международный коммерческий арбитражный суд”) при Торгово-промышленной палате РФ была сформулирована точка зрения, согласно которой указанное Постановление утратило силу как противоречащее последующему законодательству России (государственные суды, насколько известно автору, по этому поводу хранили и хранят молчание. Исключением является только позиция Судебной коллегии по гражданским делам Верховного Суда РФ и мнение заместителя Председателя Верховного Суда РФ, описываемые ниже). Но при этом возникает вопрос: с какого момента действие Постановления 1978 г. прекратилось? Большинство специалистов в российском праве полагает, что норма этого Постановления об особом порядке подписания 
утратила силу с 3 августа 1992 г., то есть с момента начала применения на территории России Основ гражданскопо законодательства Союза ССР и республик 1991 г., которые уже не содержали специальное понятие "порядок подписания внешнеторговой сделки", а ограничивались требованием соблюдения формы такой сделки

Однако при этом следует учитывать, что до 1 января 1995 г. в России продолжала оставаться не отмененной часть 2 статьи 45 Грахданского кодекса

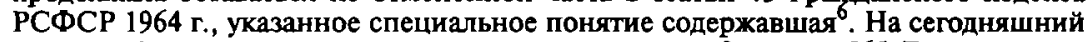
же день формально не является отмененной часть 2 статьи 565 Грахданского кодекса РСФСР 1964 г. (на которую ссылалась указанная статья 45), содержащая понятие "порядок подписания бнешнеторговьх сделок". Кроме того, в новом Гражданском кодексе РФ имеется статья 168 "Недействительность сделки, не соответствующей захону или иным правовым актам", применение которой, при условии признания Постановления 1978 г. действуюшим, может рассматриваться как влекущее недействительность внешнеэкономической сделки, подписанной одним лицом.

Ввиду всего этого вопрос о силе нормы о двух подписях мог и может рассматриваться как не до конца ясный.

\section{2. РЕIIЕНИЕ АРБИТРАЖНОГО СУДА}

Отмеченные нюансы частично нашли отражение в решении Арбитражного Суда, который пришел, в частности, к следующим выводам (здесь и в других цитируемых нихе документах названия сторон заменены понятиями "Истец" и "Ответиик", а вместо имени физического лица использовано буквенное обозначение с пояснением статуса этого лица):

"В то время как Статьей 14 Кредитного Соглащения предусмотрено, что соглашение и его толкование регулируются шведским законодательством, вопрос о том, какое лицо или лица долмсны правомочно представлтьь Ответчика при заключении соглашения, ө принципе, долхсен решаться на основе государственного законодательства этой компании, т.е. российского законодательства. В этам отношении Арбитражсним Судом принимается во внимание то, что согласно советскому Постановлению от 14 февраля 1978 г., межкдународные торговые контракты далжсны подписываться с советской стороны двумя лицами. Хотя мнения разделились относительно того, оставалось ли данное Постаноление в силе после 3 авзуста 1992 2., даты вступления в России в силу Основньо палохений Грахсданского Законодательства 1991 года, Арбитразсньй Суд считает, ито до этой даты Постановление, вазмохсно, яалялось действующим российским законам. Следовательно, мосут существовать серьезнье сомнения по поводу юридической действительности соглашения, которое, как Кредитное Соглащение, было подписано до 3 августа 1992 г., если оно не отвечало требованиям Постановения.

Поскальку Кредитное Соглащение было подписано только однии лицом, отсюда следует, что по крайней мере сомнительно, что оно изначально являлось юридически обязательным к исполнению соглашением, причем эти самнения сущестоуют незаөисимо от следующего вопроса касательно наличия у г-на $X$ [лища, подписавщего саглащение от имени Ответчика] палнамочий на подписание саглащения. Тем не менее, Арбитрахный Суд не находит нужсныи занинать окончательную позицию по вопросу об изначальной действительности Кредитного Соглашения, поскальку суцествует ряд другшх обстоятельств, подтвержсдаюцих вывод о так, что стороны следует рассматривать как принявиие на себя обязательства, вытекающие из данного соглащения.

... Кредитное Согламение далгое время признавалось обеими сторонами как инструмент, регулирующий их хозяйстөенные отнощения. Обе стороны рассматриөали данное соглащение как действующее мехду ними и действовали соответствующим образом. Генеральным директором Ответчика был подписан ряд документов, 
имеющих отнощение к исполнению Кредитного Соглащения, что имело место и после 3 августа 1992 года, т.е. в период, когда факт сохранения силы Постановлением от 14 февраля 1978 года, требующии подписания мезидннародньх торговьх договоров двумя лицами, был весима сомнительным. Не существует и подтверэсдений того, что действительность Кредитного Соглащения когда-либо оспаривалась Ответчикам прежсде, чем было начато арбитрахсное разбирательство. Напротив, в ряде документов, подписанных г-ном Y [генеральньии директором Ответчика], признавалась задалхсенность какпании по соглащению, допускался факт просрочек платехса и принимались планы дальнейшего испалнения соглашения. ...

Исходя из обстоятельств настоящего дела, когда взаимоотнощения сторон в течение значительного периода времени действительно регулировались Кредитнын Саглашением, и стороны регулярно совершали действия на этой основе, они долхсны рассматриваться как сөязанные данным соглачением, а Ответчик долзсен рассматриваться как непозвалительно ссылающийся на формальные пробелы, которые могли иметь место в момент первоначального подписания данного соглащения" "

В итоге в августе 1995 г. Арбитражным Судом было вынесено решение о взыскании с ответчика суммы долга и процентов в валюте Швеции.

\section{Aнаmз pemenus Apбuтparmoro Cyan}

1. Безусловно, Арбитражный Суд, исходя из обстоятельств дела, правильно решил, что последующие действия сторон указывали на то, что они рассматривали себя связаныыми кредитным соглашением. Тем не менее, это вовсе не значило, что с точки зрения Постановления 1978 г. (и с точки зрения российского права, если данное Постановление рассматривать как его часть) такое кредитное соглашение было обязательно для сторон: для первых любое последующее поведение сторон никак не могли заменить собою особую процедуру подписания внешнеторговой сделки, ввиду чего для них кредитное соглашение продолжало являться ничтожным, какие бы действия стороны ни осуществляли.

2. Отвлекаясь от вопроса о праве, применимом к самому кредитному соглашению и к его форме, следует указать на то, что Арбитражный Суд данное обстоятельство в своем решении не учел. Межлу тем, коль скоро он признал, что

"могут существовать серьезные сомнения по поводу коридической действительности соглашения, которое, как Кредитное Соглашение, было подписано до 3 августа 1992 г., если оно не отвечало требованиям Постановения",

коль скоро ему могла быть известна предшествующая практика применения Постановления в российском праве и коль скоро его решение должно было исполнятъся в России, он, как представляется, мог бы выднинуть дополнительные соображения, обосновывающие действительность кредитного соглашения. Учитывая, что особая процедура подписания последнего сторонами осуществлена так и не была, такие соображения должны были состоять только в обосновании неприменимости к кредитному соглашению Постановления 1978 г. ввиду утраты последним силы уже на момент заключения такого соглашения (тем более, что, как будет показано ниже, соответстнующие доводы, исходя из содержания российского права, имелись, и они были очень и очень несомы).

3. Однако, Арбитражный Суд предпочел иной путь: серьезно сомневаясь в изначальной действительности кредитного соглашения, он счел, что действия сторон, предпринятые после 3 августа 1992 г., свидетельствуют, тем не менее, о его силе. Данный вывод мог основываться только на том соображении, что после 3 августа 1992 г. Постановление 1978 г. силу утратило. Но дахе и в этом плане Арбитражный Суд проявил недостаточную последовательность, указав в решеHии:

"Генеральным директорам Ответчика был подписан ряд докунентов, имеющих отношение к испалнению Кредитного Соглашения, что имело место и после 3 августа

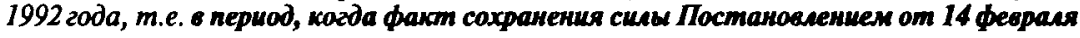




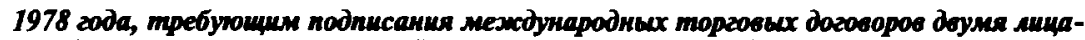
мu, быс весыма самишпевыни" (выделение мое - М.A.).

Мехду тем, действительность кредитного соглашения не могла вызывать сомнений только в одном из двух случаев: либо если на момент его подписания Постановление 1978 г. уже не действовало, либо если последнее безусловно утратило силу после 3 августа 1992 г., когда стороны своими действиями продемонстрировали обязательность для них такого соглашения. Арбитрахный Суд, не выбрав ни один из этих вариантов, предпочел третий, особенный подход, вряд ли, явившийся удачным.

\section{3. ПЕРВОЕ РАССМОТРЕНИЕ САНКТ-ПЕТЕРБУРГСКИМ ГОРОДСКИМ СУДОМ ВОПРОСА О ПРИЗНАНИИ И ПРИВЕДЕНИИ В ИСПОЛНЕНИЕ В РОССИИ РЕШЕНИЯ АРБИТРАХНОГО СУДА}

Особенностью рассматриваемого дела было то, что третье российское лицо взяло на себя в полной мере отвепственность перед шведской компанией за исполнение должником его обязательств и выдало ей гарантию (в действительности по своей природе являвшейся поручительством, если использовать термины Гражданского кодекса РФ). Поручитель исполнил свои обязательства перед шведской компанией частично. В октябре 1995 г. Арбитражным Институтом Торговой Палаты Стоктольма против него в пользу шведской компании было вынесено еще одно решение, причем на всю сумму задолженности поручителя. 9

Шведская компания выдала порупителю в Дании документ, названный "суброгационная доверенность", согласно которому поручитель имел право от своего имени и в свою пользу требовать от долхника исполнения решения Арбитражного Суда, и равным образом имел право обращаться в российские суды с требованием признать и привести это решение в исполнение в свою пользу.

- В 1997 г. поручитель как взыскатель обратился в Санкт-Петербургский городской суд (по месту нахождения долхника) с ходатайством о признании и приведении решения Арбитрахного Суда в исполнение в Россин.

Должник против удовлетворения данного ходатайства возражал, ссылаясь на Tо, что:

1) суброгационный документ оформлен ненадлежащим образом, с нарушением шведского законодательства, поскольку удостоверен не в Швеции как месте вынесения решения, а в Дании;

2) к моменту выдачи суброгационного документа пведская компания правом требования принудительного исполнения решения Арбитражного Суда уже не обладала и не могла его кому-либо передать, поскольку сам взыскатель уже исполнил данное решение;

3) исполнение решения Арбитрахного Суда будет противоречить публичному порядку Российской Федерации, поскольку Арбитражный Суд двумя различными решениями по одному и тому же обязательству произвел взыскание сначала с долхника, а затем и с взыскателя как поручителя должника;

4) исполнение решения Арбитражного Суда будет противоречигь публичному порядку Российской Федерации, поскольку оно было вынесено на основанни ничтожного кредитного соглашения, заключенного в нарушение Постановления $1978 \mathrm{r}$.

2 апреля 1997 г. Санкт-Петербургский городской суд определил, в частности, следующее (здесь и далее в цитируемых текстах опущены ссылки на листы дела. Вместо точных дат в квадратныхх скобках дано указание на месяц. Наименование поручителя, который потребовал приведения решения Арбитражного Суда в исполнение в свою польу, заменено понятием "Взыскатель"):

"Выслушав стороны, исследовав материалы дела, суд считает ходатайство подлежсацим частичнаму удовлетворению.

Доверенность на передачу прав Нстиа действительно оформена в Дании... . 
Однако, ө настоящем судебном заседании Взыскателеи представлен документ Управления патентов и регистрации, подтверэсдающий действительность выщеуказанной доверенности.

У суда также нет оснований самневатьсл в правильности перевода суброгационной доверенности..., так как он надлезсаще заверен... .

Вместе с тем, суд считает, что Истеи мог передать Взыскателю свое право требования испалнения решения [вынесенного в августе 1995 г.] талько в его неиспалненной части.

Как видно из доверенности..., первоначального текста ходатайства, зачеркнутого представителями Взыскателя в настоящем судебном заседании...; банковских счетов... Взыскатель на 21.09.1995 2. выплатил Истиу... шведские кроны в счет погашения далга по решению [вынесенному в августе 1995 г.].

Довод представителей Взыскателя о том, что данная сумка уплачена по решению Стокгальмского Арбитрахсного суда [вынесенному в октябре 1995r.](nриобщено в настоящем заседании), суд считает неубедительньн, поскалыку последнее вынесено позднее вышеуказанной частиной оплаты далга.

Таким образом, суд считает, что решение [вынесенное в августе 1995 г.] подлемсит принудительнаму испалнению талько в его неиспалненной части, то-есть за минусам... шведских крон.

Из содержания вынеприведенных решений Стокгальмского Арбитрахса видно, что по нин действительно произведено взыскание одного и того зме далга: вначале $с$ далхсника - Oтветиика по решению [вынесенному в августе 1995 г.], а затем с Взыскателя, как гаранта Ответиика, по решению [вцнесенному в октябре 1995 г.], что подтверхадется и сторонами в настоящем заседании.

Однако, суд считает, ито в испалнении решения [вынесенного в августе 1995 г.] не мохсет быть отказано по мотиву его противоречия пубицнаку порядку Российской Федерации, поскольку оно вынесено и вступило в законную силу до возникновения кализии щведского и российского права, которая образовалась только после өынесения решения [в октябре 1995 г.].

На основании излохсенного, $\mathrm{cm}$. V Конвенции о признании и приведении в испалнение иностранньх арбитрахньс рещений, ратифицированной 10.08.1960 г., Указа Президиума Верховного Совета СССР от 21.06.1988 2. "О признании и испалнении в СССР решений иностранных судов и арбитрахкей"

ОПРЕДЕЛИЛА....".

В итоге Санкт-Петербургский городской суд разрешил только частичное исполнение вынесенного в августе 1995 г. решения Арбитражного Суда, отказав во взыскании с должника той суммы, которая уже была ранее уплачена взыскателем шведской компании. При этом в резолютивной части своего определения Санкт-Петербургский городской суд использовал следующую формулировку: "Резрешить на территории Российской Федерации принудительное испалнение решения Арбитрахсного Института Торговой Палаты г. Стокгалыма, ШІвеции [вынесенного в августе 1995 г.] в части взыскания с Ответиика в паеыу Нстиа основной суммы 6 размере... шведскцх крон с перечислением всех взысканньх сумм - пасыу Bзыскапеал" (выделение мое - M.A).

\section{Аналіз отределения Сангт-Петербургского городского суда}

1. Как видно из текста определения Санкт-Петербургского городского суда, он отверг первое и третье из вышеуказанных возрахений дољкника, никак не прореагировал на четвертое и согласился со вторым. В определении нельзя не заметить и стремление суда $\mathbf{x}$ очень неразвернутой оценке аргументов сторон и очень краткому изложению своей позиции.

Анализируя последнюю, можно утверждать, что если отклонение первого 
возрахения дотжника с формальной точки зрения вполне понятно и не требует отделыных пояснений, то игнорирование четвертого не является объяснимым.

2. Что же касается второго аргумента должника, то Санкг-Петербургский городской суд, основывая на нем свой отказ в признании и приведении в исполнение решения Арбитражного Суда в полном объеме, исходил, вероятно, из следующих ошпбочных рассуждений: а) шведская компания и взыскатель захлючили договор уступки требования в отношении права требовать на основании решения Арбитрахного Суда взыскание с долхника в полной мере; б) но обладала ли шведская компания таким правом?; в) нет, в полной мере она им не обладала: после того как она получила в частичное удовлетворение денежную сумму от взыскателя, у нее данное право сохранилось такоке только частично, а именно в сумме, не покрытой платежом нзыскателя; r) соответственно, она не могла передать свое право требовать взыскания с должника в полной мере, а могла передать его только в упомянутой части.

Возможно, суд руководствовался и чем-то иным, но чем - установить из его определения невозможно.

2.1. Представляется, что с подобной цепочкой рассухдений согласиться нельзя. Прежде всего, следует признать, что шведская компания и вэыскатель цессию не совершали.

На самом деле шведская компания и взыскатель исходили из того, что к взыскателю как поручителю, исполнившему обязательство, переходят права кредитора в том объеме, в котором поручитель удовлетворил требование кредитора. Очевидно, что иначе и быть не может, исходя, по менышей мере, из содержания российского материального права, с точки зрения российского суда должного быть применимым к отношенкям шведской компании и поручителя в силу коллизионной нормы пункта 1 статьи 166 Основ грахданского законодательства Союза ССР и республик 1991 г. $^{10}$. В самом деле, пункт 1 статьи 365 Грахданского кодекса РФ (в момент исполнения поручителем своих обязательств перед шведской компанией уже на них распространявшийся ${ }^{11}$ ) предусматривает: "К порупителю, испалнияшену обязательство, переходят права кредитора по этану обязательстөу и права, принадлехсавиие кредитору как залогодерзсателю, ө там обьеме, в которам поручитель удовлетворил требование кредитора". При этом согласно пункту 2 этой же статъи кредитор был обязан вручить поручителю документы, удостоверяющие требование к долкнику, и передать права, обеспечивающие это требование (то есть речь не могла идти о договорной передаче прав требования $\mathrm{k}$ должнику). Возможно, что в действительности отношения шпедской компании и поручителя регулировались не российским материальыым правом, однако, в отсутствие информации об этом исходить из тахого предположения не следует.

Однако, при всем при этом шведская компания и взыскатель для большей, вероятно, весомости требований последнего $\mathrm{k}$ должнику оформили еще и документ, который они не совсем удачно назвали доверенностью, пусть даже и суброгационной. Последнее обстоятельство могло создавать превратное впечатление о действительньх отношениях сторон и могло ввести Санкт-Петербургский городской суд в заблуждение. ${ }^{12}$

2.2. Сказанное указывает на то, что взыскатель в действительности мог получить от должника ту большую сумму, которую он уплатил шведской компании, тогда как на оставшуюся менышую сумму он права не имел. Однако, Санкт-Петербургский городской суд решил совершенно наоборот: он признал, что взыскатель имеет право получить от должника меньшую сумму, в то время как на большую он права не имеет. Само собой разумеется, что данный вывод был бы верен в отношении шведской компании, но никак не взыскателя. Столь причудливый результат стал возможным, вероятно, только в результате неправильной квалификации Санкт-Петербургским городским судом отношений шведской компании и взыскателя: ему не следовало считать, что первая передает 
какие-либо права второму по собственной воле; ему следовало исходить из того, что такие права переходят ко второму как поручителю независимо от воли первой и только в силу факта исполнения обязательства за должника. Тем не менее, следует еще раз повторить, что взыскатель мог невольно ввести Санкт-Петербургский городской суд в заблуждение использованием доверенности и утверждениями о том, что право на взыскание было передано ему шведской компанией. Если бы это действительно было так, то Санкт-Петербургский городской суд был бы совершенно прав: получив удовлетворение от поручителя, шведская компания не могла не утратить права требования к должнику, и речь об их передаче в порядке цессии идти не могла.

2.3. В связи со сказанным следует отметить следующее очень важное обстоятельство: Санкт-Петербургский городской суд основное внимание уделил вопросу о формальной действительности суброгационного документа, а не вопросу о том, на каком сущностном основании взыскатель требует признать и привести в исполнение решение Арбитражного Суда. Если бы речь шла просто о том, что взыскатель действует от имени шведской компании и в ее интересах, то все было бы очень просто. Но на самом деле он действовал от своего имени и в собственных интересах, хотя и ссылаясь на документ шведской компании, неудачно названный доверенностью.

Соответственно, возникал вопрос: коль скоро права шведской компании как кредитора подтверждаются решением Арбитражного Суда, то в том случае, когда к взыскателю как поручителю, исполнившему кредитору за должника обязательства последнего, такие права требования переходят автоматически, должны ли они рассматриваться как носящие подтвержденный и неоспоримый характер, как могущие быть реализованными в России на основании иностранного в России решения Арбитражного Суда и при помощи специальной процедуры признания и приведения его в исполнение, или же они должны рассматриваться иначе, и для их принудиттельной реализации необходимо предъявление отдельного иска против должника? Иными словами, вставал вопрос: являются ли тахие перешедшие к взыскателю права неразрывно связанными с решением Арбитражного Суда, и приобретает ли поручитель одновременно с правами требования $k$ должнику статус, аналогичный статусу изначального кредитора (в части признания и приведения арбитражного решения в исполнение), в пользу которого такое решение вынесено или же нет?

Данная проблема в российском праве не разрешена ни на уровне законодательства, ни на уровне судебной практики. Насколько известно автору настоящей статьи, не рассматривалась она и в литературе.

Таким образом, у Санкт-Петербургского городского суда была возможность попытаться ответить на этот вопрос. Однако он ею не воспользовался. Это случилось, вероятно, все по той же причине: Санкт-Петербургский городской суд полагал, что взыскатель приобрел права требования к должнику в результате цессии. Возможно, именно этим объясняется то, что в своем определении Санкт-Петербургский городской суд разрешил исполнение решения Арбитражного Суда именно в пользу шведской компании, но с перечислением всех взыскиваемых сумм в пользу взыскателя.

3. Достаточно сложно оценить и реакцию Санкт-Петербургского городского суда на третье возражение должника о том, что исполнение решения Арбитражного Суда будет противоречить публичному порядку Российской Федерации, поскольку Арбитражный Суд двумя различными решениями по одному и тому же обязательству произвел взыскание сначала с должника, а затем и с взыскателя как поручителя должника. В своем определении Санкт-Петербургский городской суд указал:

"Из содержания вышеприведенных решений Стокгольиского Арбитражса видно, что по ним действительно произведено взыскание одного и того же далга: вначале 
с далхсника - Ответчика по решению [вынесенному в августе 1995 г.], а затек - с Взыскателя, как гаранта Ответчика, по решению [вынесенному в октябре 1995 г.], что подтверхсдается и сторонами в настоящем заседании.

Однако, суд считает, ито в испалнении решения [вынесенного в августе 1995 г.] не можсет быть отказано по мотиву его противоречия публичнаку порядку Российской Федерации, поскольку оно вынесено и вступило в законную силу до возникновения калиизии шведского и российского права, которая образовалась только после вынесения рещения [в октябре 1995 г.]".

Вероятно, Санкт-Петербургский городской суд по причине все той же неправильной квалификации отношений шведской компании и взыскателя счел, что, с точки зрения российского права, является недопустимым последовательное вынесение в пользу кредитора решений о взыскании долга как с догжника, так и с поручителя (хотя это и не так: вынесение таких решений возможно. Другое дело, что невозможно одновременное исполнение того и другого ${ }^{13}$ ), тогда как с точки зрения шведского права такое вполне допустимо. Соответственно, суд, очевидно, имел в виду, что после “неправильного" вынесения второго решения против любого из последних указанных лиц, если только они являются российскими, между российским и шведским правом возникает противоречие, которое он назвал "коляизией иведского и российского права". Далее, данное сухдение можно понимать так, что наличие подобной "каллизии" ведет к тому, что исполнение второго решения на территории Российской Федерации противоречило бы публичному порядку последней. Но так как, по мнению Санкт-Петербургского городского суда, к моменту вступления в силу решения Арбитражного Суда "камизия шведского и российского права" еще отсутствовала, то противоречие российскому публичному порядку не имелось и не имеется, ввиду чего такое решение может быть признано и приведено в исполнение.

По поводу данного мнения Санкт-Петербургского городского суда можно сказать лишь то, что оно ошибочно во всех своих аспектах: последовательное вынесение решения как против долхника, так и против поручнтеля с точки зрения российского права является возможным; понятием "коллизия законов" традиционно обозначается несколько иное явление; исполнение на территории России второго решения как такового публичному порядку Российской Федерации не противоречило бы при условии, что первое решение не исполнено.

Соответственно, даже если бы решение Арбитражного Суда в пользу кредитора против должника было вынесено после того, как было вынесено решение в пользу кредитора против взыскателя как поручителя, то исполнение первого на территории Российской Федерации ее публичный порядок не нарушало бы, при условии, что второе решение в России не было исполнено. Ввиду этого СанктПетербургский городской суд совсем неправильно решил, что возможность исполнения в России решения Арбитражного Суда против должника зависит от того, было ли вынесено решение против поручителя или нет: такая возможность отсутствовала бы только тогда, когда второе решение было бы исполнено в России в пользу кредитора, причем на всю сумму долга. Тогда, действительно, можно было бы говорить о том, что повторное взыскание долга с долхкика протиноречит публичному порядку Российской Федерации, в качестве одной из основ которого можно рассматривать принцип Non bis in idem.

4. Вызывает некоторое удивление ссылка Санкт-Петербургского городского суда на Указ Президиума Верховного Совета СССР от 21 июня 1988 г. № 9131-ХІ "О признании и исполнении в СССР решений иностранных судов и арбитражей"” Действительно, до вступления в ситу Закона РФ от 7 июля 1993 г. № 5338-I "О международном коммерческом арбитраже" (основанного на типовом законе ЮНСИТРАЛ 1985 г.) этот Ухаз регулировал вопросы приведения в исполнение иностранных арбитражных решений. Однако с 12 августа 1993 г., то есть с момента обретения силы упомянутым Законом, именно последний стал регули- 
роватъ вопросы признания и приведения в исполнение иностранных арбитрахньх решений. Тах, пункт 1 статьи 35 "Признание и приведенне в исполнение арбитражного решения" этого Закона предусматривает: "Арбитрахсне решение, независимо от того, в какой стране оно было вынесено, признается обязательным и при подаче в компетентный суд письменного ходатайства приводится в исполнение с учетом палохсений настоящей статьи и сматьи 36". Соответственно, Указ Президиума Верховного Совета СССР от 21 июня 1988 г. № 9131-XI с 12 августа 1993 г. долкен применяться в России только в части, не противоречащей Закону РФ "О международном коммерческом арбитраже". Между тем, отличия между двумя этими актами действительно значительны и даже концептуальны.

Так, Закон исходит из того, что "Арбитрахсное решение, независико от того, в какой стране оно было өынесено, признается обязательнын...". Соответственно, указываемые в статье 36 этого Закона обстоятельства являются не более чем основаниями, позволяющими достигать исключений из общего правила обязательности арбитражного решения.

Мехду тем, Указ исходит из того, что иностранное арбитрахное решение обязательной силой не обладает и в задачу российского государственного суда входит ответ на вопрос о том, следует ли разрешить исполнение такого решения, придать ему исполнительную склу по соответствующему ходатайству заинтересованного лица или же не следует. Правда, при этом те обстоятельства, ввиду наличия которых суд вправе не разрешать исполнение, носят исчерпываюший характер.

Таким образом, Закон делает акщент на обязательности арбитражного решения, а Указ делает акщент на необходимости отсутствия оснований, препятствующих выдаче разрешения привести арбитрахное решение в исполнение ${ }^{15}$.

Из этого же вктекают и различия между Законом и Указом по поводу установления и доказывания обстоятельст, наличие которьх исключает приведение арбитрахного решения в исполнение: Закон возлагает бремя доказывания преимущественно на сторону, против которой направлено решение, а из Указа следует, что суд вправе устанавлинать такие обстоятельства ех officio. Имеется и ряд других вахньх отличий Закона от Указа.

Мехду тем, Санкт-Петербургский городской суд почему-то ссылку на Закон РФ "О международном коммерческом арбитраже" не сделал.

5. Вызывает вопросы и использованная Санкт-Петербургским городским судом формулировка о том, что принудительное исполнение решения Арбитражного Суда в части взыскания с должниха денежной суммы разрешается в пользу шведской компании, но с перечислением всех взысканных сумм в пользу взыскателя. Если ходатайство о признании и приведении в исполнение решения Арбитрахного Суда было подано в Санкт-Петербургский городской суд взыскателем от своего имени и в своих интересах, то почему же исполнение этого решения было допущено в пользу именно шведской компании? Вероятно, это произошло опять-таки по причине уже упоминавшейся неправильной квалификащия Санкт-Петербургским городским судом отношений такой компании и взыскателя.

6. Следует также отметить, что взыскатель, вероятно, не только невольно ввел в заблухдение Санкт-Петербургский породской суд по поводу своего статуса, но и сам до конца не разобрался в своих правах и тех проблемах, которые возникли на стадии исполнения решения Арбитражного Суда. Все еше могло осложняться обстоятельствами, указанными в девятой сноске к настоящей статъе. Именно этим могут объясняться путаные объяснения взыскателя по поводу того, на каком основании он произвел платеж шведской фирме.

7. Наконец, и долхник до конца не разобрался в своих правах и тех проблемах, которые возникли на стадии исполнения решения Арбитражного Суда. Очевидно, что он мог быть частично прав, утверждая, что к моменту выдачи 
суброгационного документа шведская компания правом требования принудительного исполнения решения Арбитражного Суда уже не обладала (при условии, что последняя получила частичное удовлетворение от поручителя). В самом деле, в таком случае права требования перешли именно к последнему. Соответственно, пользуясь неопределенностью российского законодательстна в данном вопросе, должник мог утверждать, что права, перешедшие к поручителю, не связаны с решением Арбитрахного Суда и для их принудительного осуществления необходимо отдельное решение российского суда против него. Именно данный аргумент, а не какой-либо другой из вышеуказанных, мог бы оказаться со стороны должника наиболее сильным.

\section{4. РАССМОТРЕНИЕ ВЕРХОВНЫМ СУДОМ РОССИЙСКОЙ ФЕДЕРАЩИИ ВОПРОСА О ПРИЗНАНИИ И ПРИВЕДЕНИИ В КСПОЛНЕНИЕ В РОССИИ РЕШЕНИЯ АРБИТРАЖНОГО СУДА}

Взыскатель не согласился с частичным приведением в исполнение решения Арбитражного Суда и обжаловал определение Санкт-Петербургского городского суда в Верховный Суд РФ. 22 мая 1997 г. Судебной коллегией по грахданским делам Верховного Суда РФ по данному делу было вынесено определение, которым определение Санкт-Петербургского городского суда было полностыю отменено, и дело было направлено на новое рассмотрение в тот же суд.

Судебная коллегия в своем определении указала, в частности:

"Взыскатель обратился с ходатайствам о принудительном испалнении указанного решения, сославиись на то, что Истец (Швечия) передал ему право требования принудительного исполнения данного решения."

- Представитель Ответчика возражал против удовлетворения ходатайства и пояснил, что доверенность оформлена ненадлежаще, с нарушением Шведского законодательства, поскольку удостоверена не в Швеции, а в Дании, ко времени выдачи доверенности Истец правом требования принудительного исполнения решения не обладал, поскольку Взыскатель исполнил данное решение, перечислив Истцу взыскиваемую сумму, а, кроме того, решение противоречит публичному порядку РФ.

По делу постановлено указанное быше определение.

В частной жалобе Взыскателем ставится вопрос о6 отиене указанного определения в части отказа в удоалетворении ходатайства по тек основанияи, что суд, разрешая прикудительное испалнение решения на территории $Р \Phi$, удолетвори ходатайство лищь частично, что противоречит действуюоцему захонодательству.

Судебная коллегия по грахданским делам Верховного Суда РФ находит постановленное по делу определение подлежацим отмене в полном объеме.

Суд проверял доводы Ответчика о том, что доверенность на передачу прав Истиа офорклена в Дании, но обозрев представленный документ Управления патентов и регистрации..., подтверэсдающий действительность выщеуказанкой доверенности, обоснованно прищел к выводу о том, ито Взыскатель өправе был обратиться в суд с настоящим ходатайством.

Вместе с тен, разрешая ка территории РФ прикудительное испалнение указанного выше рещения, суд прищел к выводу о так, что Истец мог передать Взыскателю право требования исполнения рещения [вынесенного в августе 1995 г.] только в его неисполненной части.

Между тем, с таким выводом суда согласиться нельзя.

Дейстоительно, из материалов дела видно, что Взыскатель на 21 сентября 1995 года выплатил Нстиу... иведских крон в сиет погашения долга.

При этом суд указал в решении, что довод Взыскателя о том, что эта сумма уплачена по решению Арбитрахсного института Торговой Палаты в 2. Стокгалыме 
[вынесенному в октябре 1995 г.], считает неубедительньм, поскольку это рещение вынесено позднее частичного погашения долга.

Однако, делая такой вывод, суд не учел, что при заключении Кредитного соглашения между Ответчиком и Истцом, Взыскатель являлся гарантом и безусловно гарантировал наплежащее выполнение всех обязательств заемшика (Ответчика) по этому Кредитному соглашению и по первому письменному требованию незамедлительно выплатить все суммы задолженности в соответствии с порядком и сроками, определенными соглашением, так если бы они являлись вместо заемщика главным должником... .

Из материалов дела видно, что дело в отночении Взыскателя было передано Институтом на рассмотрение Арбитрахного Суда [в январе 1995 г.], т.е. до вынесения решения [в августе 1995 г.], о чем Взыскателю было известно.

Поскольку заявитель выполнил свои обязательства перед Истцом, последнии передал ему принадлежсащее ей право требования исполнения Арбитражного решения и полной оплаты в соответствии с указанным решением, то он вправе был, в соответствии с действующим законодательством, ставить перед судом вопрос о принудительном исполнении Арбитражного решения в полном объеме.

В соответствии со $\mathrm{cm}$. III Конвенции Организации Объединенньх Наций о признании и приведении в исполнение иностранных Арбитрахсньх решений (ратифицированной СССР 24 августа 1960, правопреемником которого с 24 декабря 1991 года в полном объеме является Российская Федерация) каждое Договаривающееся государство признает арбитражные решения как обязательные и приводит их в исполнение в соответствии с процессуальными нормами той территории, где испрашивается признание и приведение в исполнение этих решений.

Поскольку суд пришел к выводу о том, что указанное выше Арбитражсное решение подлежст принудительному исполнению на территории $Р \Phi$, то в силу указанной Конвенции оно должсно быть исполнено в палном объеме в соответствии с действующим законодательством РФ.

Вместе с тем, в силу п. $1 \mathrm{nn}$. b cm. V данной Конвенции, в признании и приведении в испалнение арбитражсного решения может быть отказано по просьбе той стороны, против которой оно направлено, только если сторона представит компетентной власти по месту, где испрачивается признание и приведение в исполнение, доказательство того, что признание и приведение в исполнение этого решения противоречит публичному порядку этой страны.

В материалах дела имеется возражсение на ходатайство от Ответчика..., где инеется ссылка на действующее Постановление Совета Министров СССР от 14 февраля 1978 года “О порядке подписания внешнеторговых сделок”, в нарушение которого указанное өыще Кредитное соглащение было подписано однии лицом, в чем усматривается нарушение публичного порядка. Этот документ не был предметом рассмотрения суда, хотя имеет существенное значение для данного дела.

Кроме того, в силу ст. 75 Конституции РФ денежсной единицей в $Р \Phi$ является рубль, следовательно все расчеть межсу сторонами на территории РФ должны вестись в рублевом эквиваленте, в том числе и взыскиваемые по решению суммы".

\section{Анализ определения Судебной коллепи}

В данном определении обрашают на себя внимание несколько моментов.

1. Во-первых, Судебная коллегия по грахданским делам Верховного Суда РФ правильно квалифицировала отношения шведской компании и взыскателя и, поправив Санкт-Петербургский городской суд, верно указала на то, что поручитель, осуществивший кредитору исполнение за основного должника, сам становится на место первоначального кредитора и может получить от должника все то, на что имел право такой кредитор. Однако, сделанные до этого вывода Судебной коллегией ссылки на формальную действительность все той же уже упоминавшейся доверенности, на вытекающее из нее право взыскателя обращаться в 
российский суд за исполнением решения Арбитражного Суда, заставляют несколько усомнитъся либо в последовательности такой позиции Судебной коллегии, либо в ее четкости. В самом деле, выше уже указывалось, что цессия мехду шведской компанией и взыскателем, строго говоря, не была возможной. Следует предположить, что именно из этого и исходила Судебная коллегия, хотя употребленные ей формулировки не являлись точными.

2. Во-вторьх, если считать, что Судебная коллегия отвергла возможность цессии между шведской компанией и взыскателем, тогда из ее определения вытекает достаточно важное для российского права заключение: в условиях, когда российский поручитель исполняет иностранному кредитору за российского должника обязательство последнего, и имеется вынесенное в пользу кредитора иностранное арбитражное решение, то права кредитора, переходящие к поручителю, мохно рассматривать как носящие подтвержденный и неоспоримый хаpaктер, как могущие быть реализованными в России на основания такого иностранного арбитражного решения. Иными словами, поручитель не обязан предъявлять отдельный иск к дољжнику, но приобретает в отношениях с ним статус, аналогичный статусу первоначального кредитора, в пользу которого вынесено такое решение и на этом основании вправе добиваться взыскания долга с дољжника при помощи специальной процедуры признання и приведения этого решения в исполнение, даже если он в нем и не поименован как сторона, и в арбитражном разбирательстве он не участвовал. Иными словами, в данной ситуации поручитель приобретает права кредитора именно из вынесенного в ползу последнего иностранного арбитрахного решения.

Таким образом, можно считать, что Судебная коллегия по грахданским делам Верховного Суда РФ заняла в данном вопросе определенную позицию, тогда как Санкт-Петербургский породской суд сделать это необходимым не счел.

- 2.1. Вместе с тем, нельзя не признать, что такая позиция была выражена Судебной коллегией более чем нечетко и некоторые сомнения по поводу того, действительно ли именно ее Судебная коллегия имела в виду, остакотся. Так, использование последней слов "Поскальку заявитель выпалнил свои обязательства

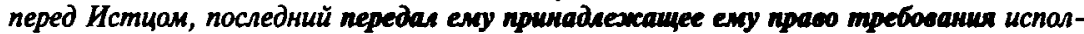
нения Арбитрахсного решения и палной оплаты в соответствии с указанньм решением" (выделение мое - М.А.) могут создать впечатление, что речь идет об уступке в пользу взыскателя прав требования шведской компании из решения Арбитрахного Суда.

Ввиду этого нельзя исключать того, что Судебная коллегия в действительности указала на допустимость цессии прав из арбитражного решения и возможность для цессионария требовать признания и приведения такого решения в Россин в исполнение без необходимости предъявления отдельного иска $\mathbf{x}$ долхнику. Следует отметить, что если это так, то заслуживает внимания следующее обстоятельство: подобный вывод был сделан до момента вступления в силу Федерапного закона от 21 июля 1997 г. № 119-Ф3 “Об исполнительном производстве”, статья 32 "Правопреемство в исполнительном производстве” которого косвенно допускает возможность цессии в отношении прав из исполнительного документа ("В случае выбытия одной из сторон (смерть грахсданина, реорганизация юридическаго лица, уступка требования, переөод далга) судебный пристая-испалнитель обязан своим постановленем произвести замену этой стороны ее правопреемникам, определенным в порядке, установленнам федеральньм законам. Дая правопреемника все действия, совершенные до его вступления в исполнительное производство, обязательны в той мере, к какой они были бы обязательны для стороны, которую правопреемник заменил").

2.2. Однако, все-таки следует исходить из того, что вряд ли именно указанное в предыдущем абзаце имела в виду Судебная коллегия: иначе зачем она отменила определение Санкт-Петербургского городского суда и упомянула о гарантии 
взыскателя? Представляется, что эти два последних момента поворят о том, что Судебная коллегия не могла не учитывать то, что шведская компания после получения удовлетворения от взыскателя как поручителя утратила свои права требования к долхнику и, соответственно, ничего в порядке цессии передавать не могла ${ }^{17}$.

Соответственно, далее автор будет исходить из того, что Судебная коллегия по грахданским делам Верховного Суда РФ отвергла возможность цессии между шведской компанией и взыскателем.

2.3. Но является ли основательным мнение Судебной коллегии о том, что в условиях, когда российский поручитель исполняет иностранному кредитору за российского должника обязательство последнего, и имеется вынесенное в пользу кредитора иностранное арбитражное решение, то права кредитора, переходящие к поручителю, можно рассматривать как носящие подтвержденный и неоспоримый характер, как могушие быть реализованными в России на основании такого иностранного арбитрахного решения? Представляется, что в современном российском праве содержатся некоторые положения, на которых данное мнение может основываться.

Тақ, учитывая, что получение поручителем прав к должнику является переходом прав на основании закона ${ }^{18}$ и что статья 384 Грахданского кодекса РФ устанавливает: “Если иное не предусмотрено законом или договором, право первоначального кредитора переходит к новому кредитору в том обвеме и на тех условиях, которые суиеетвовали к моменту перехода права", можно утверждать, что последняя норма должна толковаться как имеющая в виду, в том числе, и такое качество получаемых поручителем прав, как их вытекающий из иностранного арбитражного решения подтвержденный и неоспоримый характер, допускающий то, что поручитель не обязан предъявлять отдельный иск к долхнику, но приобретает в отнопениях с ним статус, аналогичный статусу первоначального кредитора, в пользу которого вынесено подобное решение и на этом основании вправе добиваться принудительного взыскания долга с должника при помощи специальной процедуры признания и приведения этого решения в исполнение, даже если он в нем и не покменован ках сторона и в арбитражном разбирательстве он не участвовал.

Кроме того, в польэу такого толкования косвенно свидетельствует Постановление Президиума Высшего Арбитрахного Суда РФ от 17 июня 1997 г. № 1533/97 (в котором было признано, что на включенное в договор соглашение об избрания определенного арбитража дия разрешения возможньх споров между участниками этого договора в силу все той же статьи 384 Гражданского кодекса РФ распространяются правила о цессии ${ }^{19}$ ), а также уже упоминавшаяся статья 32 Федерапьного закона "Об исполнительном производстве".

Тахим образом, оба вышеприведенньх примера демонстрируют, что определенные субъективные права, вытекающие из таких имеющих в своей природе в той или иной степени продессуальные элементы институтов, как арбитрахная оговорка и арбитражное решение, могут приобретаться при помоши грақданскоправовых средств, в частности, в результате перехода прав по сделке или на основании закона. Соответственно, все это указывает на возможность тото, что в условиях, когда российский поручитель исполняет иностранному кредитору за российского долкника обязательство последнего, и имеется вынесенное в полыу кредитора иностранное арбитражное решение, то права кредитора, переходящие к поручителю, мохно рассматривать как носящие подтвержденный и неоспоримый характер, как могушие быть реализованными в России на основании такого иностранного арбитражного решения.

Следует особо отметить, что использованный в указанном выше Постановлении Президиума Высшего Арбитражного Суда РФ от 17 июня 1997 г. № 1533/97 критерий необходимости соблюдения и соотношения прав должника и лица, 
получившего права, может быть успешно применен и в отношении рассматриваемой ситуации для обоснования возможности того, что поручитель может приобрести права кредитора именно из вынесенного в пользу последнего иностранного арбитражного решения. В самом деле, права должника в данном случае никак не ушемляются: ему должно быть все равно, кому платить. Равным образом и поручитель не пользуется в отношении должника какими-либо правами, которые отличались бы от прав к должнику первоначального кредитора.

2.4. Само собой разумеется, что подобный подход может вызывать и возражения. Так, против него могут свидетельствовать общие соображения о необходимости полного выяснения в ходе отдельного процесса содержания обязательств должника перед поручителем, доводы о процессуальной и строго формальной лрироде вынесенного решения, не допускающей замены указанной в нем стороны, а также сложившаяся во внутреннем российском обороте практика, при которой кредитор обращается к поручителю с отдельным иском даже тогда, когда его иск к основному должнику удовлетворен, а не требует исполнения вынесенного уже решения, полагая, что указанный в нем ответчик подлежит замене на поручителя ${ }^{20}$, равно как и практика, при которой и поручитель обращается с отдельным иском к должнику ${ }^{21}$.

Далее, можно указать и на то, что в отличие от Президиума Высшего Арбитражного Суда РФ Судебная коллегия по гражданским делам Московского городского суда в своем определении от 21 апреля 1997 r. $^{22}$ решила, что цессия не влечет автоматически перемену лиц в арбитражном соглашении. В частности, ей было указано: "Однако даже если признать передачу прав по Соглашению об управлении правомочной, это не может быть распространено на арбитражное соглашение.

Исходя из принципа автономности арбитражного соглащения, согласно которому арбитражная оговорка, явлющаяся частью контракта, должсна рассматриватьсї в качестве автономного процессуального соглащения, независимого от остальньх условий контракта, передача прав по арбитражсному соглашению должна быть оформлена специально, писименным соглашением или путем заключения нового арбитражного соглащения...". Очевидно, что такой подход является выражением иной позиции, согласно которой определенные субъективные права, вытекающие из таких имеюших в своей природе в той или иной степени процессуальные элементы институтов, как арбитражная оговорка и арбитражное решение, не могут приобретаться при помощи обычных гражданско-правовых средств, в частности, в результате перехода прав по сделке или на основании закона.

Наконец, вряд ли можно представить такую ситуацию, при которой во внутреннем российском частноправовом обороте поручитель сможет потребовать выдачи ему исполнительного листа против должника ввиду того, что решение против последнего в пользу кредитора уже было российским государственным судом вынесено и поручитель исполнил кредитору обязательства за должника.

Все эти аргументы действительно существенны, но Судебная коллегия по гражданским делам Верховного Суда РФ предпочла им иной подход (вместе с тем, автору настоящей статьи в свете действующего российского законодательства, его смысла и исходных начал более основательным представляется позиция, противоположная подходу Судебной коллегии). Не сомневаясь в праве последней на такой подход, в то же время следует подчеркнуть, что она могла бы, несомненно, обосновать его более аргументировано, учитывая, к тому же, что в данном случае речь шла о сложном вопросе взаимодействия материальных и процессуальных аспектов. Кроме того, это было бы тем более оправдано, если учесть молчание российского права по данному интересному вопросу и наблюдающееся различие между подходами к нему не только российских государственных судов общей юрисдикции и арбитражных судов, но различие между подходами Верховного Суда РФ и Московского городского суда. 
3. Далее, Судебная коллегия допустила еше одну серьезную неточность: как следовало из материалов дела, взыскатель как поручитель по-прежнему являлся погасившим задолженность кредитору только частично. Соответственно, даже если он и мог требовать от должника уплаты денежной суммы именно на основании решения Арбитражного Суда, то очевидно, что это не могла быть вся сумма, в таком решении указанная. Возможно, взыскатель как поручитель успел уплатить шведской компании всю сумму задолженности и представил Судебной коллегии доказательства этого. Но тогда последняя могла бы данное обстоятельство отразить в своем определении, чтобы не допускать противоречия или, по меньшей мере, неясности. Если же взыскателем шведской компании была уплачена не вся сумма задолженности, то возникает вопрос: на каком основании в пользу первого было допушено взыскание с должника в полном объеме, учитывая, что в таком случае права к нему от кредитора перейти в полном объеме не могли. И тут мы подходим к еше одному важному выводу, сделанному Судебной коллегией, и к еще одной существенной неточности, ею же допущенной.

4. Итак, в-третьих, Судебная коллегия, учитывая довод взыскателя о недопустимости частичного исполнения иностранного арбитражного решения, сделала следуюший очень важный вывод: она указала на то, что в силу Конвенции о признании и приведении в исполнение иностранных арбитражных решений (Нью-Йорк, 1958 г.), иностранные арбитражные решения, коль скоро допустимость их исполнения в России признана, подлежат исполнению в ней в полном объеме, а не в частичном. Поскольку российское законодательство данный вопрос не регулирует, подобное указание является очень и очень ценным. Неточность же состоит в том, что Судебная коллегия не указала, представил ли ей взыскатель доказательства того, что он как поручитель уплатил шведской компании за должника всю сумму.

Если он это сделал, то тогда вывод Судебной коллегии о том, что иностранные арбитражные решения, коль скоро допустимость их исполнения в России признана, подлежат исполнению в ней в полном, а не в частичном объеме, согласуется с ее же выводом о том, что поручитель вправе добиваться взыскания долга с должника при помощи специальной процедуры признания и приведения в исполнение иностранного арбитражного решения, даже если он в нем и не поименован как сторона, при условии, что такое решение было вынесено в пользу кредитора до того, как поручитель исполнил ему обязательства за должника. Однако если такие доказательства не были представлены, то следует признать, что первый вывод Судебной коллегии о том, что иностранные арбитражные решения, коль скоро допустимость их исполнения в России признана, подлежат исполнению в ней в полном объеме, не является логичным.

В самом деле, в ситуации, в которой поручитель исполнил кредитору обязательства за должника не в полном объеме, первый из отмеченньх выводов (допустимость приведения в исполнение в полном объеме) сосуществовать со вторым (возможность реализации поручителем своих прав на основании арбитражного решения) не может. Если мы допускаем правильность первого, мы при одновременном согласии со вторым приходим к крайне несправедливому результату: в пользу взыскателя как поручителя могут быть взысканы суммы, на которые он никакого права не имеет, поскольку он сам не исполнил кредитору обязательства за должника в полной мере.

Если же мы допускаем правильность второго вывода, то мы должны отвергнуть первый: в самом деле, разве может поручитель, к которому перешла только часть прав первоначального кредитора, подтвержденных арбитражным решением, требовать признания и приведения такого решения в исполнения в свою пользу, зная, что оно должно быть автоматически признано исполнимым именно в полном объеме? Очевидно, что нет, и тогда для поручителя остается один путь: 
он должен предъявлть самостоятельный иск к должнику в пределах тех сумм, которые он как поручитель уплатил кредитору. Таким образом, определекие Судебной коллегии в данном деле окончательно все запутало.

В итоге автор настоящей статьи считает, что Судебная коллегия по гражданским делам Верховного Суда РФ сделала неправильные выводы, так что на самом деле приведение иностранного арбитражного решения в исполнение частично является возможным, а поручитель не может добиваться взыскания долга с должника при помощи специальной процедуры признания и приведения в исполнение иностранного арбитражного решения, вынесенного в пользу кредитора до того, как поручитель исполнил ему обязательства за должника. Доводы в пользу такого мнения уже приводились выше.

5. В-четвертых, Судебная коллегия обратила внимание на валютный аспект рассматриваемого дела. Исходя из содержания норм валютного законодательства Российской Федерации, следует признатъ, что Судебная коллегия могла и должка была обратиться к этому вопросу, и что она правильно указала на то, что все расчеты между должником и взыскателем могут осушествляться только в российской валюте, исходя из рублевого эквивалента взыскиваемых сумм, причем независимо от того, что взыскатель как поручитель уплатил шведской компании иностранную валюту ${ }^{23}$.

Правда, нельзя не заметить, что такое указание Судебной коллегии может рассматриваться как находящееся в противоречии с ее же указанием на то, что коль скоро допустимость исполнения иностранного арбитражного решения в России признана, то оно подлежит исполнению в ней в полном, а не в частичном объеме. И хотя по сути дела такое противоречие в действительности с точки зрения российского права отсутствует, было бы последовательнее, если бы Судебная коллегия по грахданским делам Верховного Суда РФ объяснила, в чем причины такого отсутствия.

6. В-пятых, Судебная коллегия допустила фактическую ошибку: вместо подпункта $b$ ) пункта 2 статьи V Конвенции о признании и приведении в исполнение иностранных арбитрахных решений (Нью-Йорк, 1958 r.) она сослалась на подпункт b) пункта 1 этой же статьи. Но, более того, она неправильно воспроизвела подпункт b) пункта 2 статьи V, спутав два основания установления обстоятельств, препятствующих признанию и приведению в исполнение иностранного арбитражного решения, так что в итоге получилось нечто среднее между подпунктами b) пунктов 1 и 2 статьи $V$ данной конвенции (подпункт b) такого пункта 1 предусматривает представление соответствующих доказательств стороной, против которой направлено решение, в то время как подпункт b) пункта 2 устанавливает для компетентной власти возможность по собственной инициативе определить, имеются ли такме обстоятельства) ${ }^{24}$.

7. В-шестых, что самое главное, предпоследний абзац из процитированного отрывка определения Судебной коллегии ("B материалах дела имеется возрахсение на ходатайство от Ответчика..., где инеется ссылка на дейстьующее Постановление Совета Министров СССР от 14 февраля 1978 года "O порядке подписания внешнеторговьх сделок", в нарушение которого указанное выие Кредитное соглашение было подписано одним лицан, в чем усматривается наруиение пубиичного порядка. Этот документ не был предметак рассмотрения суда, хотя uкеет существенное значение для данного дела") можно понимать так, что Судебная коллегия рассматривала Постановление 1978 г. как действующее, причем даже и в 1997 г., и что при подписании кредитного соглашения оно не было соблюдено, в чем усматривается нарушение публичного порядка. Возможно, Судебная коллегия вовсе и не имела в виду то, на что сейчас было указано. Тем не менее, скупость использованных ею формулировок оставляет болышое поле для усмотрения. Более того, содержание приводимого ниже ответа заместителя Председа- 
теля Верховного Суда РФ позволяет считать, что имелось в виду все же именно это.

8. Имеется еще один достаточно существенный момент: Судебная коллегия указала на то, что нарушение публичного порядка усматривается ввиду подписания ,кредитного соглашения, в то время как речь должна была идти о противоречии публичному порядку ввиду признания и приведения решения Арбитражного Суда в исполнение. Очевидно, что это две различные вещи и известно, что и подпункт b) пункта 2 статьи V Конвенции о признании и приведении в исполнение иностранных арбитражных решений (Нью-Йорк, 1958 г.), и подпункт 2 пункта 1 статьи 36 Закона РФ "О международном коммерческом арбитраже" 25 в качестве основания для отказа в признании и приведении в исполнение арбитражного решения устанавливают противоречие публичному порядку именно таких признания и приведения в исполнение.

Направляя дело на новое рассмотрение, Судебной коллегии, по меньшей мере, следовало, например, пояснить, что ее указание на нарушение публичного порядка Российской Федерации следует понимать так, что Санкт-Петербургскому городскому суду необходимо выяснить, не повлечет ли признание и приведение решения Арбитражного Суда в исполнение нарушение публичного порядка Российской Федерации, учитывая, что подписание кредитного соглашения, на основании которого было вынесено данное решение, уже явилось его нарушениeM.

9. Наконец, Судебная коллегия по гражданским делам Верховного Суда РФ не обратила внимания на моменты, указанные выше в пунктах 4 и 5 анализа определения Санкт-Петербургского городского суда.

10. Что же касается должника, то он опять-таки не смог воспользоваться доступными ему средствами правовой защиты.

Во-первых, пользуясь допуценным Судебной коллегией противоречием в вопросе о соотношении проблемы исполнения в России иностранных арбитражньх решений именно в полном, а не в частичном объеме, с проблемой права поручителя добиваться взыскания долга с должника при помощи специальной процедуры признания и приведения в исполнение иностранного арбитражного решения (даже если он в нем и не поименован как сторона, но при условии, что такое решение было вынесено в пользу кредитора до того, как поручитель исполнил ему обязательства за должника), должник мог утверждать, что права, перешедшие к взыскателю как поручителю, не связаны с решением Арбитражного Суда и для их принудительного осуществления необходимо отдельное решение российского суда против него (тем более, что реалии российского права позволяли ему так утверждать).

Во-вторых, должник также мог заявить, что права, перешедшие к взыскателю как поручителю, не связаны с решением Арбитражного Суда и для их принудительного осуществления необходимо отдельное решение российского суда против него, так как именно этого требуют: а) соображения о необходимости полного выяснения в ходе отдельного процесса содержания обязательств должника перед поручителем; б) процессуальная и строго формальная природа вынесенного решения Арбитражного Суда, не допускающей замены указанной в нем стороны; в) сложившаяся во внутреннем российском обороте практика, при которой кредитор обращается к поручителю с отдельным иском даже тогда, когда его иск к основному должнику удовлетворен, а не требует исполнения вынесенного уже решения, полагая, что указанный в нем ответчик подлежит замене на поручителя, равно как и практика, при которой и поручитель обращается с отдельным иском к должнику.

В-третьих, должник мог утверждать, что права взыскателем как поручителем получены от кредитора в результате регресса, а не в порядке перехода прав на основании закона. Данный момент является весьма принципиальным: в случае с 
регрессом можно утверждать, что между поручителем и должником возникает новое обязательство. "От замены кредитора при цессии регрессное требование отличается тен, что происходит не только замена кредитора, но и возникает новое обязательство с самостоятельными требованияии" 26 . Но если это так, то говорить о том, что взыскатель ках поручитель мог получить от кредитора права, могущие быть реализованными на основании решения Арбитрахного Суда, невозможно. Безусловно, такой аргумент с точки зрения статьи 387 Грахданского кодекса РФ не выдерживает критики, но с практической точки зрения он мог реально помочь должнику.

В-четвертых, если это позволяли обстоятельства дела, должник мог утверждать, что отношения шведской компании с взыскателем как поручителем регулировались не российским материальным правом, а каким-либо иностранным, согласно которому поручитель, исполнивший кредитору обязательства за долокника, получает права от кредитора в порядке регресса, а не в порядке перехода прав на основании закона. Соответственно, как следует из выпшеизоженного, это могло бы быть сильным аргументом в пользу того, что права, перешедшие к взыскателю как поручителю, не связаны с решением Арбитражного Суда и для их принудительного осуществления необходимо отдельное решение российского суда против должника.

\section{5. РАССМОТРЕНИЕ ЗАМЕСТИТЕЛЕМ ПРЕДСЕДАТЕЛЯ ВЕРХОВНОГО СУДА РОССИЙСКОЙ ФЕДЕРАЦИИ ВОПРОСА О ПРИНЕСЕНИИ ПРОТЕСТА НА ОПРЕДЕЛЕНИЕ СУДЕБНОЙ КОЛЛЕГИИ}

Взыскатель не согласился с проанализированнњм выше определением Судебной коллегии по гражданским делам Верховного Суда РФ и подал в Верховный суд РФ заявление с просьбой принести на него протест.

- Заместитель Председателя Верховного Суда РФ отказался это сделать и в своем ответе на заявление взыскателя указал, в частности:

“Сообщаю, что Ваща жалоба на определение судебной каллегии по гражданским делам Верховного Суда РФ от 22.05 .97 2. nо делу по Вашему ходатайству о разрешении принудительного испалнения рещения Арбитрахсного Института Торговой Палаты 2. Стокгольма по иску Истиа (Швеция) к Ответиику рассмотрена ө Верховном Суде Российской Федерации в порядке надзора.

Oпределением судебной каллегии по граэсданскик делам Санкт-Петербургского городского суда от 2.04 .97 г. на территории Российской Федерации было разрешено принудительное исполнение реиения Арбитрахсного Института Торговой Палаты z. Стокгальма (ІІвеция) [вынесенного в августе 1995 г.] в части взыскания $c$ Ответчика в пальзу Истиа денежсньо суми, в валюте ІІвеции.

Согласно п. I п.п. б. ст. 5 Конөенции Организации Объединенньх Наций о признании и приведении в испалнение иностранньх Арбитрахньх рещений, ратифицированной СССР 24.08.60 2., правопреемникам которого с 24.12.91 2. в палном обвеме яаляется Российская Федерация, в признании и приведении в испалнение арбитрахного решения мозсет быть отказано по просьбе той стороны, против которой оно направлено, талько если эта сторона представит компетентной власти по месту, где испрашивается признание и приведение в испалнение, доказательство того, ито признание и приведение в исполнение этого решения противоречит публинному порядку этой страны.

Кредитное соглашение, заключенное мехху Ответчикам и Истиам 24.06 .92 г., в нарушение постановления Совета Министров СССР от 14.02.78 2. "O порядке подписания внешнеторговых сделок", действовавщего на тот период времени, было подписано одним лицам, что является нарущением публичного порядка.

Хотя данный документ имеет существенное значение для дела, он не был предметом рассмотрения суда.

Краме того, в силу ст.75 Конституиии РФ денежсной единицей в РФ является 
рубль, следовательно все расчеты между сторонами на территории РФ должны вестись в рублевом эквиваленте, в том числе и взыскиваемые по решению суммы.

Ссылка в жалобе на ст. 317 ГК РФ, в соответствии с которой при осуществлении расчетов на территории РФ возможно использование иностранной валюты, является несостоятельной, поскольку на момент заключения кредитного соглащения новый гражданский Кодекс еще не был принят.

При таких данньх коллегия обоснованно отменила вышеназванное определение суда и дело направила на новое судебное рассмотрение.

Жалоба оставлена без удовлетворения".

\section{Анализ ответа заместителя Председателя Верховного Суда РФ}

1. В этом ответе опять-таки обращает на себя внимание фактическая ошибка по поводу подпунктов b) пунктов 1 и 2 статьи V Конвенции о признании и приведении в исполнение иностранных арбитражных решений (Нью-Йорк, 1958 г.).

Кроме того, неточность была и в указании на то, что Санкт-Петербургский городской суд разрешил исполнение решения Арбитражного Суда против должника в пользу шведской компании: хотя в определении Санкт-Петербургского городского суда это действительно было сказано, однако затем шло упоминание о том, что взыскиваемые суммы подлежат перечислению в пользу взыскателя.

Нельзя согласиться и с доводом третьего с конца абзаца в тексте ответа по поводу принятия нового Гражданского кодекса РФ: невозможность, по общему правилу, расчетов между резидентами России в иностранной валюте вытекает из отечественного валютного законодательства, и даже если бы новый Гражданский кодекс РФ действовал в момент заключения между шведской компанией и должником кредитного соглашения, это еще не значило бы, что такие расчеты возможны.

2. Заместитель Председателя Верховного Суда РФ также не обратил внимания на противоречие, допушенное Судебной коллегией в вопросе о соотношении проблемы исполнения в России иностранных арбитражных решений именно в полном, а не в частичном объеме, с проблемой права поручителя добиваться взыскания долга с должника при помощи специальной процедуры признания и приведения в исполнение иностранного арбитражного решения (даже если он в нем и не поименован как сторона, но при условии, что такое решение было вынесено в пользу кредитора до того, как поручитель исполнил ему обязательства за должника).

3. Далее, заместитель Председателя Верховного Суда РФ еще более определенно высказался по поводу Постановления 1978 г. Он указал, что кредитное соглашение было подписано в нарушение Постановления 1978 r., и что это являлось нарушением публичного порядка. Правда, он ограничился указанием на то, что Постановление 1978 г. действовало в период заключения кредитного соглашения, в то время как позиция Судебной коллегии по гражданским делам Верховного Суда РФ могла быть понята и так, что Постановление 1978 г. продолжало действовать в том числе и в 1997 г.

4. Кроме того, заместитель Председателя Верховного Суда РФ повторил еще одну ошибку Судебной коллегии, ограничившись указанием на то, что нарушение публичного порядка было совершено подписанием кредитного соглашения не в соответствии с Постановлением 1978 г. На самом же деле речь должна была идти о том, что противоречить публичному порядку должно признание и приведение решения Арбитражного Суда в исполнение.

5. Наконец, заместитель Председателя Верховного Суда РФ не обратил внимания на моменты, указанные выше в пунктах 4 и 5 анализа определения Санкт-Петербургского городского суда.

6. Учитывая вышеизложенное, можно утверждать, что заявление о принесе- 
нии протеста на определение Судебной коллегии по грахданским делам Верховного Суда РФ было рассмотрено в Верхонном Суде РФ формально.

\section{6. ОЦЕНКА ПОЗИЦИИ ВЕРХОВНОГО СУДА РОССИЙСКОЙ ФЕДЕРАЩИИ В ОТНОШЕНИИ ДЕЙСТВИЯ ПОСТАНОВЛЕНИЯ 1978 Г. И КАТЕГОРИИ "ПУЕЛИЧНЫЙ ПОРЯДОК"}

Даже если допустить, что подписание кредитного соглашения в нарушение Постановления 1978 г. повлекло противоречие публичному порядку Российской Федерации, это еще, по мнению автора настоящей статьи, не означало автоматически того, что признание и приведение решения Арбитрахного Суда в исполнеңие имело бы результатом противоречие тому же самому публичному порядку ${ }^{27}$.

Но были ли правы Судебная коллегия по грахданским делам Верховного Суда РФ и заместитель Председателя Верховного Суда РФ, считая, что кредитное соглашение было подписано в нарушение Постановления 1978 г., и могла ли Судебная коллегия в 1997 г. говорить о Постановлении 1978 г. как о дейстнующем акте? Положительные ответы на эти вопросы могут иметь очень вахные правоные и практические последствия и могут существенным образом повлиять на внешнеэкономические связи российских субъектов права: по меньшей мере, мохет быть поставлена под сомнение не тольо действительность подписанных ранее и действующих до сих пор сделок, но и более того, иностранные контрагенты российских субъектов всегда должны будут требовать от последних подписания внешнеэкономических сделок двумя лицами. Принимая во внимание часть 3 пункта 3 статьи 7 Закона РФ от 21 ноября 1996 г. № 129-Ф3 “О бухталтерском учете" расчетные документы, финансовые и кредитные обязательстөа считаются недейстөительньми и не далэсны приниматься к испалнению", можно допустить, что при таком подходе соответствуюшие внешнеэкономические сделки должны будут подписываться тремя лицами, а это уже граничит с абсурдом.

Автор настояшей статьи полагает, что и Судебная коллегия по гражданским делам Верховного Суда РФ, и заместитель Председателя Верховного Суда РФ пришли к ошибочным выводам, а Постановление 1978 г. утратило силу задолго до подписания положенного в основу решения Арбитражного Суда хредитного соглашения, несмотря на то, что данное Постановление формально в России не приостанавливалось и не отменялось. Попутно можно заметить, что автор настоящей статьи не разделяет преобладающую в российской доктрине точку зрения, согласно которой Постанонление 1978 г. утратило силу тольхо с 3 августа 1992 г., то есть с момента начала применения на территории России Основ гражданского законодательства Союза ССР и республик 1991 г., которые уже не содержали специальное понятие "порядок подписания внешнеторговой сделки", а ограничивались требованием соблюдения формы такой сделки. Подробное опровержение такой точки зрения уже было осушествлено автором ${ }^{29}$, ввиду чего повторять его не следует.

Прежде всего, необходимо оценить значение и смысл принятия Постановления 1978 г. Его основополагающий пункт 1 гласил: "Установить, что:

өнешнеторговые сделки, заключаемые советскини организациями, правомочныни совершать внешнеторговые сделки, далжсны подписываться дөумя лицами. Право подписи таких сделок имеют руководитель и заместители руководителя указанной организации, руководители фирм, входяцих в состав этой организации, а такаке лица, упалнамоченные доверенностами, подписанными руководителем организации единолично, если уставом (поломсением) организации ке предусмотрено иное. ...

Имена и фамилии лиц, имеюцих по далэсности право подписи внешнеторговьх сделок, а такжсе векселей и других денезкньх обязательств, публикуются в печатнан 
органе Министерстөа өнешней торгови или в печатнам органе министерства, государственного камитета или ведамства, в системе которого находится соответстөующая организация". Было бы глубокой ошибкой рассматривать данные нормы как простую формальность, созданную советским правом.

Если мы вспомним, какое значение придавалось в СССР принципу монополии советского государства на внешнюю торговлю ${ }^{30}$, то оценить роль и смысл нормы Постановления 1978 г. о двух подписях можно в полной мере. Монополия внешней торговли являлась одним из фундаментов, на которьх базировалась плановая экономика СССР. Следовательно, советское государство нуждалось в специальном механизме для идеального, с точки зрения советских подходов, функинонирования этой монополии. Прежде всего, он состоял в наделения правом выхода на внешний рынок только небольшого числа организаций, обладающих, $\mathrm{k}$ тому же, что весьма существенно, специальной правоспособностью. "В соответствии с өыражсенным в Конституции СССР принципам государственной монополии внешкей торгови советское законодательство определяет круг тех советских организаций, которые пальзуются правам совершения сделок по экспорту и икпорту" 31 . Но это являлось недостаточным: был необходим дополнительный механизм контроля над совершением внешнеторговых операций внутри таких обладающих спещиаљной правоспособностью юридических лиц. Отсутствие подобного механизма могло бы быть для Советского государства весьма негативным: несмотря на декларируемую отдельную правосубъектность посударственньх организаций от государства, они составляли, по сути дела, с ним одно целое, и неконтролируемое совершение внешнеторговьх сделок неуполномоченными лицами вполне могло привести $\mathbf{x}$ финансовой несостоятельности внешнеторговых объединений, а посредством этого создавалась бы угроза финансовой стабильности государства и особенно угроза вапотнњм резервам, в которых СССР всегда испытывал недостаток.

Поэтому норма о двух подписях играла очень важную роль в механизме монополии внешней торговли в СССР: она являлась дополнительным инструментом контроля над совершением внешнеэкономических сделок внутри внешнеторговых объединений. Хотя эта норма и устанавлинала, на первый взгляд, не более чем формальность, последняя носила глубокий смысл, итрала значительнейшую роль и влекла существенные последствия: важны были не подписи сами по себе, а факт санхционирования сделки лицами, специально уполномоченными внешнеторговым объединением, которое, в свою очередь, было на это управомочено государством. Последнее посредством механизма нормы о двух подписях фактически санкционировало каждую внешнеторговую сделку. Ввиду всех этих факторов норма о двух подписях действительно не могла не иметь в СССР особого значения и не могла не характеризоваться особой императивностъю. Учитывая значение и роль внешнеэкономических связей для СССР, можно сказать, что от ее соблюдения зависело не только идеальная работа механизма монополии внешней торговли, но через последнюю - и успешное фунхионирование всей плановой экономики.

Таким образом, норма о двух подписях являлась неразрывно связанной с советской монополией внешней торговли и социалистическим плановым хозяйством. В этом были ее основания существования, цели и смысл. Неудивительно, что она первоначально была законодательно закреплена в СССР в начале 30-x годов, в период изменения лодходов $\mathbf{k}$ внешней торговле, государственная монополия на которую всегда была особым принципом советской власти, направленным на ее укрепление.

Очень важно отметить, что особой процедуре подписания внешнеторговых сделок Постановлением 1978 г. был придан характер публичной достоверности: фамилии и имена лиц, имеющих право подписывать внешнеторговые сделки, публиковались в общедоступных печатных органах, в частности, в специали- 
зированном журнале “Внешняя торговля". По этой причине любые попытки неуполномоченного лица заключить внешнеторговую сделку и посредством ее обязать внешнеторговое объединение были обречены на неудачу: благодаря указанной публичной достоверности было невозможно утверждать, что иностранный контрагент не знал об отсутствии полномочий у лица, сделку совершившего.

Ввиду этого можно утверждать, что в СССР норма Постановления $1978 \mathrm{r}$. относилась к нормам "позитивного" публичного порядка. Именно этим объясняется, в частности, практика применения Постановления 1978 г. Внешнеторговой арбитражной комиссией при ТПП СССР, когда нарушавшие это Постановление сделки признавались недействительными.

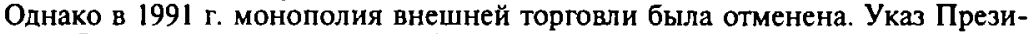
дента РСФСР от 15 ноября 1991 г. № 213 “О либерализации внешнеэкономической деятельности на территории РСФСР" 32 , вступивший в силу с момента его подписания, установил: " $B$ целях стимулирования внешнеэкономической деятельности, стабилизации внутреннего рынка и привлечения иностранных инвестиций постановляю:

1. Разрешить всем зарегистрированным на территории РСФСР предприятиям и их объединениям независимо от форм собственности осуществление внешнеэкономической, в том числе и посреднической, деятельности без спечиальной регистрации".

Весь глубокий смысл и значительнейшая роль нормы о двух подписях исчезли вместе с устранением монополии внешней торговли. Но нельзя считать, что устанавливаемое этой нормой требование наличия двух подписей продолжало сохранять силу, пусть даже и в качестве формальности. Вывод может быть только один: норма Постановления 1978 г. о двух подписях утратила все основания своего существования, отпали все преследуемые ею цели, и она стала для регулирования правового оборота ненужной. Более того, отмена в России монополии внешней торговли и начало перехода к рыночной экономике стали теми факторами, которые кардинально изменили смысл правового регулирования. В результате норма о двух подписях стала противоречить смыслу и сути нового российского законодательства. Следовательно, в соответствии с пунктом 2 Постановления Верховного Совета РСФСР от 12 декабря 1991 г. № 2014-1 “О ратификации Соглашения о создании Содружества Независимых Государств" 33 эта норма перестала быть применимой на территории России как противоречащая новому российскому законодательству, его принципам и смыслу.

Очень характерно то, что при выдвижении утверждений о действии нормы Постановления 1978 г. о двух подписях (до 3 августа 1992 г. или после этой даты), почему-то совсем забывают объяснить, каким образом должна была соблюдаться другая норма Постановления 1978 г. о публичной достоверности данных о лицах, уполномоченных на подписание внешнеторговых сделок. Невозможно предположить, что последняя силу утратила, а норма о двух подписях - не утратила: они либо обе сохранили силу, либо обе утратили ее. Но после отмены монополии внешней торговли исполнять норму Постановления 1978 г. о публичной достоверности стало технически крайне сложно (если вообще возможно), а с правовой точки зрения просто бессмысленно, что еще раз доказывает утрату силы нормой о двух подписях. В противном случае и сегодня на любого субъекта внешнеэкономической деятельности следует возлагать ответственность за то, что он не опубликовал имена и фамилии лиц, имеющих по должности право подписания внешнеторговых сделок, в печатном органе соответствующего федерального ведомства (такая публикация технически очень сложна, но в принципе возможна, хотя и бессмысленна).

Кроме того, отказ от монополии внешней торговли стал одним из важнейших принципов экономики и права России, признавшей, что Commercium jure gentium commune esse debit et non in monopolium et privatum paucorum quaestum convertendum 
(По мехсдународнаку прабу торговл далхна быть всеобщей и не превращаться в монопалию и источник частной прибыли дая немногих). Сегодня этот принцип необходимо отнести к основам правопорядка Российской Федерации, и по этой причине норму Постановления 1978 г, о двух подписях следует опять-таки считать противоречащей таким основам правопорядка, внутреннему публичному порядку Российской Федерации, поскольку она является орудием совершенно противоположного подхода.

Таким образом, поскольку норма Постановления 1978 г. о двух подписях утратила силу с 15 ноября 1991 г., с момента вступления в силу Указа Президента РСФСР от 15 ноября 1991 г. № 213 "О либерализации внешнеэкономической деятельности", то не может быть речи не только о нарушении публичного порядка Российской Федеращии при наличии на внешнеэкономической сделке одной подписи со стороны российского лица, но и о простом нарушении законодательства России.

Соответственно, именно из этого могли бы исходить и Арбитрахный Суд, и Судебная коллегия по грахданским делам Верховного Суда РФ, и заместитель Председателя Верховного Суда РФ, а не ограничиваться соответственно сомнениями либо утверждениями по поводу продолженкя действия Постановления 1978 г. в России.

\section{7. ВТОРОЕ РАССМОТРЕНИЕ САНКТ-ПЕТЕРБУРГСКИМ ГОРОДСКИМ СУДОМ ХОДАТАЙСТВА О ПРИЗНАНИИ И ПРИВЕДЕНИИ В ИСПОЛНЕНИЕ В РОССИИ РЕШЕНИЯ АРБИТРАХНОГО СУДА}

В октябре 1997 г. данное ходатайство было вновь рассмотрено Санкт-Петербургским городским судом. Как следовало из актов Верховного Суда РФ, одним из решающих должен был стать вопрос о том, будет ли являться противоречащим публичному порядку Российской Федерации признание и приведение решения Арбитражного Суда в исполнение. И действительно, в ходе судебного заседания долкник настойчиво утверждал, что признание и приведенне такого решения в исполнение повлечет нарушение данного публичного порядка. По большому счету, долкнику ничего иного делать и не оставалось, учитывая, что Закон РФ "О международном коммерческом арбитраже" очень благоприятно относится $\mathrm{k}$ признанию и приведению в исполнение иностранньх арбитражных решений и для отказа в них устанавливает ограниченный перечень оснований, связанғып̆ преимущественно с формальными моментами арбитражного разбирательства, ввиду чего использование любого из таких оснований, кроме указания на противоречие публичному порядку, пля должника явллось изначально бесперспективным, коль скоро пропедурные аспекты вынесения решения Арбитрахного Суда были соблюдены ${ }^{34}$

В свою очередь, для большей весомости своей позиции взыскатель представил в Санкт-Петербургский городской суд экспертное заключение международной юридической фирмы “ММЦП \& $\mathbf{K}^{\circ}$ ". В нем был произведен детальный разбор ситуации и доказательно сделан вывод о том, что признание и приведение в исполнение решения Арбитражного Суда не будет противоречить публичному порядку Российской Федерации ввиду того, что Постановление 1978 г. утратило силу задолго до заключения кредитного соглашения между шведской компанией и долхником, а именно с 15 ноября 1991 г., то есть с момента, когда вступил в силу Указ Президента РСФСР от 15 ноября 1991 г. № 213 "О либерализации внешнеэкономической деятельности на территории РСФСР”, отменивший в России монополию государства на внешнюю торговлю. Для этого в заклочении была исследована правовая история происхождения Постановления 1978 г., его смысл и соотношение с последуюшим российским законодательством. Кроме того, в нем было продемонстрировано, к каким абсурдным правовым последст- 
виям в России может привести признание Постановления 1978 г. действующим. Наконец, в нем указывалось, что в любом случае заключение сделки, нарушающей публичный порядок, не может автоматически означать, что исполнение вынесенного на основании этой сделки иностранного арбитражного решения повлечет противоречие этому же публичному порядку ${ }^{35}$.

Данное экспертное заключение было Санкт-Петербургским городским судом принято во внимание. В итоге этот суд определил:

"При новом рассмотрении дела представитель Ответчика возразил против удовлетворения ходатайства, ссьлаясь на то, ито спорное решение противоречит публичному порядку Российской Федерации, так как Кредитное Соглашение, являвшееся предметом рассмотрения Арбитражного Института Торговой Палаты 2. Стокгольма было подписано одним лицом в нарушение Постановления Совета Министров СССР от 14 февраля 1978 года "О порядке подписания внеинеторговьх сделок". Все остальные возражения, представленные ранее Ответчиком..., в данном судебном заседании представителем Ответчика были сняты.

Выслушав стороны, проверив материалы дела, нахожу ходатайство подлежащим удовлетворению в полном объеме.

В соответствии со ст. III Конвенции Организации Объединенных Наций о признании и приведении в исполнение иностранньх Арбитражных решений (ратифицированной СССР 24 августа 1960 года, правопреемником которого с 24 декабря 1991 года в полном объеме является Российская Федерация) каждое Договаривающееся государство признает арбитражные рещения как обязательные и приводит их в исполнение в соответствии с процессуальными нормами той территории, где испрашивается признание и приведение в исполнение этих решений.

В соответствии с 4. $2 \mathrm{~cm}$. V указанной Конвенции, в признании и приведении в исполнение арбитражсного решения может быть отказано, если компетентная власть страны, в которой испрашивается признание и приведение в исполнение решения найдет, что признание и приведение в исполнение этого решения противоречит публичному порядку этой страны.

Из объяснений представителя Ответчика следует, что должник не оспаривает наличие указанного выще решения Арбитражного института Торговой Палаты 2. Стокгальна и права Взыскателя требовать исполнения этого решения на основании доверенности на передачу прав Истца.

Доводы Ответчика о недействительности Кредитного Соглащения от 24.06 1992 года, подписанного со стороны далжника одним лицом, были предметом рассмотрения Арбитражсного Института Торговой Палаты г. Стокгольма, что нашло отражсене в решении [вынесенного в августе 1995 г.]. При этом в арбитражном решении приведены исчерпывающие доводы о том, почему Арбитражсный Институт счел данное Кредитное Соглашение дейстөующим. При таких обстоятельствах суд не находит, что признание и приведение в исполнение этого рещения противоречит публичному порядку Российской Федерации".

Соответственно, Санкт-Петербургский городской суд разрешил исполнение решения Арбитражного Суда в полном объеме. Однако при этом в резолютивной части своего определения Санкт-Петербургский городской суд вновь указал: "Разрецить на территории Российской Федерации принудительное исполнение решения Арбитражного Ннститута Торговой Палаты 2. Стокгольма, ШКеции Гвынесенного в августе 1995 2.J в части взыскания с Отөетчика в пользу Истиа основной суммы... шөедских крон с перечислением всех взысканных сумм в пользу Взыскателя".

\section{Аналнз определения Санкт-Петербургского городского суда}

1. Какие-либо дополнительные аргументы в пользу своей позиции, кроме указанных выше, Санкт-Петербургский городской суд не использовал. Вполне вероятно, что удовлетворяя ходатайство взыскателя, он мог учитывать доводы, 
содержапиеся в представленном ему экспертном заключении межпународной

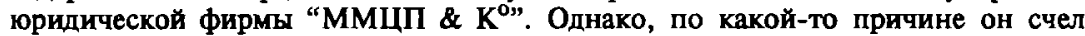
необходимым ограничиться указанием на то, что кредитное соглашение было признано Арбитрахсным Судом действительным, ввиду чего вопрос о нарушении Постановления 1978 г. и противоречии исполнения решения Арбитрахного Суда публичному порядку Российской Федерации стоять уже не мог. Санкт-Петербургский породской суд уклонился от ответа на вопрос, действовало ли в момент заключения хредитного соглашения Постановление 1978 г., хотя он мог легко придти к негативному ответу. Фактически он занял позицию Арбитрахного Суда, которая, как уже указывалось выше, вряд ли была удачной.

Равным образом Санкт-Петербургскнй городской суд предпочел не анализировать категорию "противоречие публичному порядку". Не исключено, что, придя по существу $\mathrm{K}$ правиљному выводу, данный суд счел подобный анализ излишним вли стишком затруднительным, хотя нельзя не признать, что от более развернутой аргументации в его определении российское право только выиграло бы.

2. Наконец, своим вторым определением Санкт-Петербурпский городской суд показал, что он также не обратил внимания на противоречие, допущенное Судебной коллегией по грахданским делам Верховного Суда РФ в вопросе о соотношении проблемы исполнения в России иностранных арбитрахных решений именно в полном, а не в частичном объеме, с проблемой права поручителя добиваться вэыскания долга с основного должника при помоци специальной процедуры признания и приведения в исполнение иностранного арбитражного решения (даже если он в нем и не поименован как сторона, но при условии, что такое решение было вынесено в пользу кредитора до того, как поручитель исполнил ему обязательства за должника). Об этом свидетельствует и формула резолютивной части его определения о том, что исполнение решения разрешается в пољьу шведской компании, но с перечислением всех взыскиваемых сумм в пользу взыскателя. В итоге же вместо четкого ответа на вопрос вновь имели место неопределенность и двусмысленность.

3. Но зато Санкт-Петербургский городской суд в своем втором определении уже не использовал ссылки на Указ Президиума Верховного Совета СССР от 21 июня 1988 г. № 9131-XI “О признании и исполнении в СССР решений иностранных судов и арбитрахей”. Однако при этом не сослался и на Закон РФ “О международном коммерческом арбитрахе", а ограничился упоминанием о Конвенции о признании и приведении в исполнение иностранных арбитрахных решений (Нью-Йорк, 1958 г.). Но при всем при этом он использовал терминологию Указа Презңдиума Верховного Совета СССР, говоря именно о разрешении принудительного исполнения решения Арбитрахного Суда.

4. Можно также упомянуть и о том, что Санкт-Петербурпский городской суд никак не учел указание Судебной коллегии по грахданским делам Верховного Суда РФ на то, что

"в силу ст. 75 Конституции РФ денежсной единццей в РФ яаляется рубль, следовательно, все расчеты межсду сторонами на территории РФ далжсны вестись в рублеван экөиваленте, в там числе и взыскиваемые по решению суммы".

Как ухе говорилось, исходя из норм действующего валютного законодательства России, можно утверждать, что взыскатель действительно не мог получить от долхника истребуемую сумму в валюте, но долкен был получить эквивалент этой суммы в российских рублях. Возможно, Санкт-Петербургский городской суд не стал этот вопрос рассматривать потому, что должник соответствующее возражение снял, хотя представляется, что декларируемая российским государством валютная политика требовала оr суда по собственной инициативе уделить данному аспекту особое внимание.

5. Наконец, нельзя не признать, что должник на данной стадии рассмотрения 
дела не использовал те средства правовой зашиты, которые ему предоставляли реалии российского права.

\section{8. ОБЩИЕ ВЫВОДЫ}

Рассмотренная история демонстрирует, что в России уже на стадии признания и приведение иностранных арбитражных решений в исполнение можно столкнуться с довольно неожиданными сложностями.

Не стоит еще раз подробно указывать на технические (иногда достаточно серьезные) неточности, которые иногда допускаются российскими судами, как показывает проанализированное дело. Однако следует еше раз упомянуть о серьезных правовых ошибках и противоречиях, которые, как показывает это же дело, вполне могут быть допушены в таком сложном вопросе, как признание и приведение в исполнение иностранных решений (при этом не исключается, что их количество, по мере рассмотрения дела, может только увеличиваться). Вообще же говоря, что касается и неточностей, и ошибок, то рассмотренная история является достаточно уникальной как по их количеству, так и по их значимости.

Вместе с тем нельзя не отметить и то, что российские суды пытаются сформулировать ответы на вопросы, носящие весьма принципиальный характер. Об этом в рассмотренном деле свидетельствует позиция Судебной коллегии по гражданским делам Верховного Суда РФ о необходимости исполнения в России иностранных арбитражных решений именно в полном, а не в частичном объеме, равно как и допушение ею для поручителя возможности добиваться взыскания долга с основного должника при помоши специальной процедуры признания и приведения в исполнение иностранного арбитражного решения (даже если он в нем и не поименован как сторона, но при условии, что такое решение было вынесено в пользу первоначального кредитора до того, как поручитель исполнил ему обязательства за должника). Вполне понятно, что на этом пути российскими судами делаются только первые шаги, ввиду чего некоторые ошибки и возникновение противоречий неизбежны.

Что касается других сложностей, то одна из них состоит как в том, что должники толкуют понятие "противоречие публичному порядку" очень широко и пытаются использовать его в качестве основного возражения против признания и приведения в исполнение иностранных арбитражных решений, так и в том, что подобная позиция должников нередко находит поддержку у судов, в том числе и вышестоящих. Объясняется это, прежде всего, тем, что в российском праве нет опыта применения данного понятия. Так, можно утверждать, что за всю историю существования СССР действующие в нем правоприменительные органы ни разу к нему не прибегали ${ }^{36}$... (по меньшей мере, какие-либо публикации советских судебных и иных решений или ссылки на них автору настоящей статьи не известны). Далее, этот институт очень слабо разработан и в доктрине отечественного права (сказанное следует воспринимать с поправкой на то, что до сих пор сохраняют значение написанные в начале века работы по данному вопросу Бруна М.И. ${ }^{37} \ldots$ и Пиленко A.A. ${ }^{38}$ ), а имеюшиеся труды периода после 1917 г. устарели, обладают идеологической окраской либо несерьезны. Данные обстоятельства имеют следствием то, что суды иногда дают очень причудливое истолкование категории "противоречие публичному порядку" (как показывает и описанная история), а иногда неправильно используют ее (как следует из позиции Судебной коллегии по гражданским делам Верховного Суда РФ в рассмотренном деле). Впрочем, все вышесказанное указывает и на то, что данная категория, притягивая к себе основное внимание в тех случаях, когда о ней вообще не следует говорить, в действительности может отвлекать и стороны, и суд от других, действительно острых проблем конкретного спора и слабых позиций той или иной стороны. Соответственно, эту категорию вовсе не следует переоценивать или забывать ввиду нее 06 иных аспектах дела. 
С другой стороны, сложность данной категории не следует недооценивать, особенно судам: если она и используется ими правильно, то одновременно нередко имеет место недостаточно большое внимание к ней (что опять-таки демонстрируется обстоятельствами рассмотренного дела).

Между тем, все еще больше осложняется запутанностью российского регулирования, зачастую противоречивого, формалистичного и содержащего многочисленные пробелы. Особым аспектом в этой проблеме является достаточно важный и острый вопрос о применимости старого советского права.

Кроме того, в последнее время в России складывается конкурируюшая судебная юрисдикция в сфере признания и приведения в исполнение иностранных решений ${ }^{39}$. Как известно, в России споры с участием иностранных лиц могут разрешать как государственные арбитражные суды, так и суды обшей юрисдикции. Однако при этом вопросы признания и приведения в исполнение иностранных решений по частноправовым вопросам рассматривали и рассматривают, исходя из содержания действующего законодательства, суды общей юрисдикции. Тем не менее, государственные арбитражные суды, получив в 1995 г. компетенцию рассматривать споры с участием иностранных лиц, теперь все чаше утверждают о наличии и у них компетенции решать вопросы признания и приведения в исполнение таких решений (правда, только по экономическим спорам) и, более того, уже начали использовать этот подход на практике. Соответственно, ввиду того, что в каждом из данных двух видов судов может иметься собственное понимание проблем такого признания и приведения в исполнение, выбор российского суда того или иного вида может стать определяющим в успешности попытки добиться признания и приведения в исполнение в России конкретного иностранного решения.

В результате, ввиду того, что российское право исповедует принцип благоприятного отношения к иностранным арбитражным решениям, категория "противоречие публичному порядку" в современной России является тем средством, к которому наиболее часто неправильно могут прибегать особенно должники (а иногда и суды) в стремлении обеспечить отказ в признании и приведении в исполнение таких решений в России: использование других устанавливаемых российским правом оснований для такого отказа является в преобладающем большинстве случаев бесперспективным. При этом весьма характерно и то, что, не зная, как обращаться с категорией “противоречие публичному порядку", или не желая показывать свое незнание, должники и некоторые суды нередко сложному и тонкому юридическому анализу могут предпочесть голословные утверждения о наличии подобного противоречия. В итоге кредиторам следует быть готовыми к тому, что вместо аргументов в судебных актах некоторых российских судов по поводу признания и приведения в исполнение иностранных арбитражных решений они обнаружат только выводы. Но даже если там будут присутствовать и доводы, вряд ли они будут развернутыми, что всегда будет оставлять большие возможности для различной их интерпретации.

Именно отсутствие устоявшихся в практике и теории подходов в применении категории "противоречие публичному порядку" и отсутствие каких-либо всеми признанных критериев в его отношении обусловливают то, что у многих иностранных арбитражных решений при их признании и приведении в исполнение в России имеются все шансы столкнуться с аналогичными, или даже еще большими, трудностями, которые были описаны в настоящей статье. При этом, по большому счету, не всегда будет иметь значение, идет ли речь о сложном деле или же об относительно простом.

Единственным средством противодействия этому является тщательность и глубина анализа каждой конкретной ситуации в свете особенностей российского права, причем не только на этапе признания и приведения решения в исполнение, 
но и на этапе его вынесения в форме выдвихения той или иной стороной требований к арбитрам четко ответить на определенные правовые вопросы. Так, нельзя исключать того, что позиция Арбитражного Суда, Фактически отказавшегося занять ясную позишию в сложном и болезненном для международного частного права России вопросе о действии Постановления 1978 г. и сомневавшегося в наличии силы у этого Постановления как до, так и после 3 августа 1992 г., могла способствовать тому, что при решении вопроса о признании и приведении решения Арбитражного Суда в исполнение догхник настойчиво выдвигал указание на несоответствие кредитного соглашения Постановлению 1978 г. и на вытекающее из этого противоречие признания и приведения в исполнение решения Арбитражного Суда публичному порядку Российской Федерации.

Нельзя не отметить, что в большинстве случаев залогом успеха признания и приведения решения в исполнение будет обращение кредитора к высококвалифицированным российским юристам.

В заключение следует упомянуть о том, что за последнее время было опубликовано уже три документа Верховного Суда РФ, в которых рассматривается понятие "противоречие публичному порядку", причем в двух из них применительно к решениям Международного коммерческого арбитражного суда при ТПП Р $\Phi^{40} \ldots$. При этом анализ данного понятия был осуществлен в таких документах в отличие от того, как это было сделано в рассмотренном деле, правильно ${ }^{41}$.... Соответственно, все это позволяет надеяться на то, что количество допускаемых в судебной практике ошибок в сфере признания и приведения в исполнение решений международного коммерческого арбитража будет неуклонно сокращаться.

А.И. Муранов,
партнер международной юриднческой фирмы “ММЦП \& К”,,
кандидат оридических наук,
старший преподаватель кафедры
мехдународного частного и грахданского права
МГИМО (Университета) МИД РФ,
подробнее об авторе см. в № 4 нашего журнала за 1999 год.

${ }^{1}$ Муранов А.И. Проблема порядка подписания внешнеэкономических сделок и публичный порядок Российской Федерации (по материалам одного из решений Верховного Суда России). - Московский журнал международного права, 1998, $\mathrm{Na}_{3}$

Собрание постановлений Правительства Союза Советскцх Социалистических Республик, 1978, № 6, ст. 35.

3 См., например, примеры из книги: Практика Арбитрахного суда, 19841986, часть XI. - М., ТПП СССР, секция права, 1989, с.3-4.

4 Статья 4 Закона РСФСР от 24 октября 1990 г. “О действии актов органов Союза ССР на территории РСФСР” гласит: “Акты органов СССР, изданные до прикятия настоящего Закона, действуют ка территории РСФСР, если они не приостановлены Верховным Советам РСФСР или Советам Министров РСФСР" (Ведомости Съезда народных депутатов РСФСР и Верховного Совета РСФСР, 1990, № 21, ст. 237); пункт 2 Постановленуя Верховного Совета РСФСР от 12 декабря 1991 r. № 2014-1 "О ратификации Соглашения о создании Содрухсества Независимых Государств” предусматривает: “...установить, ито ка территории РСФСР до принятия соответствуощих законодательных актов РСФСР нормы бывшего Союза ССР применяются в части, не противоречащей Конституиии РСФСР, законодательстөу РСФСР и настаящему Соглашению" (Ведомости Съезда народньх депутатов РСФСР и Верховного Совета РСФСР, 1991, № 51, ст. 1798). Розенберг М.I. Контракт мехдународной купли-продажи. Современная 
практика заключения. Разрешение споров. - М., 1996, с. 38-40. Розенберг М.Г. Контракт международной купли-продажи. Современная практика заключения. Разрешение споров. - М., 1996, с. 38-40.

6 "Несоблюдение формы внешнеторговьх сделок и порядка их подписания (статья 565) влечет за собой недействительность сделки".

7 "Форма өнешнеторговьх сделок, совершаемьх советскими организациями, и порядок их подписания, независимо от места совершения этих сделок, определяются законодательством Союза ССР".

8 Здесь и в последующих цитируемых документах сохранены, кақ правило, язык, стиль, орфография и пунктуация оригиналов. При этом такие документы по возможности приводятся максимаљьо полно, однако, с учетом целей настоящей статьи.

9 Автор настоящей статьи отмечает, что из имеющихся у него документов не было до конца ясно, почему Арбитрахный Суд вынес решение против поручителя на всю сумму долга в условиях, когда последний частично уже исполнкл перед кредитором обязательства за должника. Вероятно, ситуация могла развиваться следующим образом: поручитель добровольно погасил часть задолскенности должника, но затем было решено, что для обоснования в России такой выплаты ему не помешает иметь арбитражное решение. Соответственно, кредитор и поручитель могли договориться считать произведенный платеж никак с поручительством не связанным, ввцду чего арбитраж не мог не удовлетворить иск. Далее же по договоренности сторон истец мог отказаться от исполнения такого вынесенного в его пользу решения против поручителя.

10 "При отсутствии соглащения сторон о подлежсащеи прикенению праве применяется право страны, где учремдена, имеет место хсительства ипи основное место деятельности сторона, яаляющаяся:

ii. 12) поручителем - в договоре поручительства;...".

ii Как известно, первая часть Гражданского кодекса РФ была введена в действие с 1 января 1995 г. Статья 5 Федерального закона от 30 ноября 1994 г. 인 52-Ф3 "О введении в действие части первой Грахданского кодекса Российской Федерации" предусматривает: "По гражданским правоотношениям, возникшим до введения ее ө дейстөие, часть первая Кодекса применяется к тем правам и обязанностям, которые возникнут после введения ее в дейстьие" (Собрание законодательства Российской Федерации, 1994, № 32, ст. 3302). Между тем, взыскатель как поручитель произвел платеж шведской компании в сентября $1995 \Gamma$.

${ }_{12}$ В частности, он мог решить, что взыскатель на основании доверенности действует как агент шведской компании, а коль скоро последняя уже получила определенную сумму, вторичное взыскание этой же суммы в ее пользу является недопустимым.

${ }_{13}$ Так, в Информационном письме Высшего Арбитражного Суда РФ от 20 января 1998 г. № 28 “Обзор практики разрешения споров, связанных с применением арбитрахными судами норм Грахданского кодекса Российской

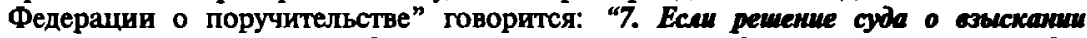

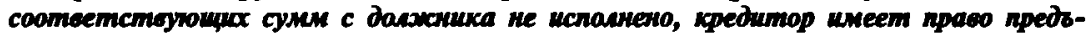
seumb иск к nopyuunewo.

Кредитор обратился в арбитрахсный суд с иском к далхкнику в связи с просрочкой возврата суммы займа.

Арбитрахсный суд иск удовлетворил и взыскап сумму займа и процентов, исчислекнь в вазмере, определекном в договоре. Испалкительный лист был предаявлен кредиторам к исполнению, но оплата произведена не была в связи с отсутствием средсто на счете далхсника.

Испалнение обязательств далжсником было обеспечено договорам поручительства. Не палучив удовгетворения по исполичтельному документу, кредитор обратился 
с иском к поручителю, несуцему салидарную ответственность с далжнникам. Поручитель просил суд освободить его от ответственности, поскальку при наличии решения о взыскании далга с должника повторное взыскание поялечет неосновательное обогащение кредитора.

Арбитрахкый суд отклонил доводы поручителя и удовлетворил требования кредитора, представивщего доказательства непалучения от далжника платехса по выданнаму ранее исполнительнаму документу. В резалютивной части решения было указано, что поручитель отвечает солидарно с основньм далэсником.

При этам суд исходил из того, что по договору поручительства поручитель обязывается перед кредитором другого лича отвечать за исполнение последним его обязательства в целам или в части. Обязательства далхсника могли считаться испалненными лищь при уплате далга кредитору, а не вынесении решения о его взыскании.

Согласно статье 323 Кодекса салидарные далзсники остаются обязанными до тех пор, пока обязательстөо не испалнено палностью.

Поскальку основное обязательство не было испалнено, кредитор был вправе на основании статьи 361 и пуккта 2 статьи 363 Кодекса обратиться к поручителю с требованиен об испалнении обязательства. При нальии доказательств, сөидетельствующцх о палной или частичной уплате далга основныи даљхникам, поручитель вправе ссылаться на эти обстаятельства в споре с кредиторам (статья 364 Кодекса)" (Вестник Высшего Арбитражного Суда Российской Федерации, 1998, № 3).

${ }^{14}$ Ведамости Верховного Совета Союза Советских Социалистических Республик, 1988, № 26, ст. 427.

15 Соттетственно, когда далее будет говорится о разрешении исполнения инотсранного решения, это будет не словоупотреблением автора настоящей статьи, а использованием им слов других лиц и судов.

${ }_{16}$ Российская газета, 1997, 5 августа; Собрание законодательства Российской Фёдерации 1997, № 30, ст. 3591.

17 Но даже если Судебная коллегия имела в виду все-таки указанное выше в пункте 2.1, то оно, тем не менее, обладает определенной ценностыо для российского права и практики признания и приведения в исполнение в России иностранных арбитражных решений.

${ }_{18}$ Статья 387 Гражданского кодекса РФ предусматрвает: “Права кредитора по обязательстөу переходят к другому лицу на основании закона и наступления указанньсх в нем обстоятельств....

өследствие исполнения обязательства должсника его поручителем или залогодателем, не явлющиися далюсником по этаку обязательстөу;...". Стоит подчеркнуть, что в отечественной литературе даже в очень серьезных изданиях иногда можно встретить ошибочные указания на то, что поручитель приобретает права $K$ должнику не в порядке перехода прав на основании закона, а в порядке регресса: "Поручителю предоставлено право регресса к долэснику, обязательство которого он өыполнил" (Комментарий к Гражданскому кодехсу Российской Федерапии части первой (постатейный), расширенный, с использованием судебно-арбитражной практики / О.Н. Садиков (рук. авт. колл. и отв. ред.). - М., 1997, с. 617).

19 "Согласко статье 384 Грахсданского кодекса Российской Федерации право первоначального кредитора переходит к новому кредитору в там объеме и на тех условиях, которые существовали к маменту перехода права, если иное не предуснотрено законом или договором.

Анализ указанной нормы и заключенного мезсду сторонами договора цессии, которым предусмотрена также уступка права на предљаление исков, позөаляет сделать следуюцие выводы.

Предвявение иска в защиту нарушенньх прав представяет собой одну из составньо частей содержания права требования, перешедчего к новому кредumopy. 
Сохранение ранее устанопенного сторонаки порядка разрешения споров не ущемляет прав цессионария и позволяет обеспечить надлемсацую защиту интересов долэсника.

Учитывая зто, обе инстанции арбитражсного суда сделали обоснованный вывод о том, что к упоминаемьм в статье 384 Гражсданского кодекса Российской Федерации условияи, на которьх права первоначального кредитора переходят $к$ новому кредитору, мохет быть отнесено такмсе условие об избрании определенного арбитражса для разрешения возможсньх споров мезжу участниками договора" (Вестник Высшего Арбитражного Суда Российской Федерацни, 1997, № 9).

${ }^{20} \mathrm{CM}$. выше сноску 13.

21 Президиум Высшего Арбитражного Суда РФ в Постановлении от 3 ноября 1998 г. № 4269/98 решпл: "Внешнеэконамическое объединение "Техмашинпорт" (Әалее - ВО “Технашимпорт") обратилось в Арбитрахсный суд Московской области с искаи $x$ товариществу с ограниченной ответственностью "Катуар-Керамика" (далее ТОО "Катуар-Керамика") о езыскании 560 929,19 далара СІІА, уплаченнъо истиам на основании гарантийного письма кредитору - Мезидународнаму московскаму банку (далее - ММБ) за заемцика (ответчика), а такэсе 5782731205 рублей 50 копеек процентов за пользование чузсими денехсными средствани за период с 01.01 .95 по 10.01.97

До принятия решения стороны заключили мировое соглащение, по которому ответчик палностью признал исковые требования и обязался передать в собственность истиу часть оборудования стоимостью, эквиөалентной сунме задолэкенности.

Oпределением от 13.02 .97 суд утвердил мировое соглашение, установив, что оно не нарушает прав других лии и в соответствии с требованияии статьи 121 и пункта 7 статьи 85 Арбитрахсного процессуального кодекса Российской Федерации прекраmun производство no делу.

В протесте заместителя Генерального прокурора Российской Федерации предлагается определение Арбитрахсного суда Масковской области от 13.02 .97 отмекить, дело направить на новое рассмотрение, поскальку мировое соллашение ущеиляет права и законные интересы ММБ.

Рассмотрев протест, Президиум не находит оснований для его удовлетворения.

Как следует из материалов дела, по кредитнаму сазлашению от 01.07.93 Межсдународный московский банк предоставил совместнаму предприятию "КатуарКерамика" (өпоследствии - ТОО "Катуар-Керамика") 2 100 000 даларов СIIA для закупки итальянскаго оборудования с конечным срокам возврата кредита через 18 месяцев с даты его использования.

Требование о возврате остальной суммы далга по кредитнаму соглашению ө соотөетствии с его условием предвявлено ММБ в Мемкдународный коммерческий арбитрахсный суд при Торгово-промышленной палате Российской Федерации. Названное требование удовлетворено за счет ТОО "Катуар-Керамика", признанного правопреекником СП "Катуар-Керамика" (заемиик).

Таким образак, оба иска (настоящий и вышеуказанный) предаяалены по самостоятельным основаниям, и они не зависимы друг от друга. Кредитор и поручитель пользуются раєными правами по отнощению к долэснику.

В соответствии с пунктак 1 статьи 365 Грахсданского кодекса Российской Федерации к поручителю, испалнивщему обязательство, переходят права кредитора по этому обязательстөу в там объеме, в котором поручитель удовлетворил требоөание кредитора. Поручитель такэке впраөе требовать от далэсника уплаты процентое на сумку, выплаченную кредитору.

ВО "Техмашиипорт", предъявив настоящий иск, реализовал право поручителя, исполнившего обязательство, по своеку усмотрению, как это установлено статьей 9 названного Кодекса" (Вестник Высшего Арбитражного Суда Российской Федераций, 1999, № 1)

${ }^{22}$ Не опубликовано. 
23 Данную позицию в 1998 г. поддерхал и Президиум Высшего Арбитрахного Суда РФ в своем Постановлении от 3 ноября 1998 г. № 4269/98: “Поскальку согласно пункту 1 статьи 317 Граххданского кодекса Российской Федерации денезсные обязательства далжсны быть вырахсены в рублях, поручитель вправе требовать от долхсника уплаты процентов в рублях на сумку, выплаченкук кредитору, неснотря на то, что основное обязательство испалнено в иностранной важоте" (Вестних Высшего Арбитражного Суда Российской Федерации, 1999, № 1).

${ }^{24}$ Статъя V этой Конвенции предусматрнвает: "1. В признании и приөедении в исполнение арбитражнного решения мозсет быть отказано по просьбе той стороны, против которой оно направлено, только если эта сторона представит каниетентной власти по месту, где испрашивается признание и приведение в испалнение, doказательства того, чmo:

a) стороны в соглащении, указанном в статье $I I$, были по применимому к ник закону, в какой-либо мере недееспособны ии это соглашение кедействительно по закону, которому стороны это соглашение подчинили, а при отсутстөии такого указания - по закоку страны, где решение было вынесено, или

b) сторона, против которой вынесено рещение, не была далхсньи образан уведамлена о назначении арбитра или об арбитрахснаи разбирательстве или по другим причинам не могла представить свои обыяснения, или

c) уксзанное решение вынесено по спору, не предуснотренноку ипи не подпадающеку под условия арбитрахсного соглашения или арбитрахсной оговорки в договоре, или содерэсит постановления по вопросак, вьходяиим за пределы арбитрахсного соглашения или арбитралсной оговорки в договоре, с тем, однако, ито если постановления по вопросам, ахватьваемын арбитрахснык соглашекиек или оговоркой, могут быть отделены от тех, которые не ахватывакотся такик соглаиением или аговоркой, то та часть арбитрахнного решения, которая содерхси постаноаления по вопросан, охватываемын арбитрахснын соглачениен или арбитразкной оговоркой - договоре, моэсет быть признана и приведена в испалнение, или

d) состав арбитрахсного органа или арбитрахсный процесс не соответствовали соглашению сторон или, при отсутствии такового, не соответствовали закону той страны, где имел место арбитрахс, или

е) решение еше не стало охончательным дяя сторон или было отменено ияи приостановено испалнением компетентной властью страны, где оно было вынесено, или страны, закон которой приненяется.

2. В признании и приведении в испалнение арбитрахсного решения мохсет бымь такхсе отказано, если компетентная аласть страны, в которой испрашивается признание и приведение в испалнение, найдет, что:

а) объект спора не мохсет быть предметом арбитрахсного разбирательства по законам этой страны, или

b) признание и приведение в исполнение этого решения противоречат публинаму порядку этой страны" (Ведомости Верховного Совета СССР, 1960, № 46, ст.421).

${ }^{25}$ Российская гезета, 1993, 14 августа; Ведомости Съезда народных депутатов Российской Федеращии и Верховного Совета Российской Федерации, 1993, № 32. c). 1240.

26. Камиентарий к Грахданскому кодексу Российской Федерации части первой (постатейный), расширенный, с использованием судебно-арбитрахной практики / О.Н. Сапиков (рук. авт. колл. и отв. ред.). - М., 1997, с. 630.

${ }_{27}$ Более подробное обоснование данного тезиса см. в работе: Муранов А.И. Проблема порядка подписания внешнеэкономических сделок и публичный порядок Российской Федерации (по материалам одного из решений Верховного Суда России). - Московский журнал международного права, 1998, № 3, с. 93.

28 Российская газета, 1996, 28 ноября.

29 Муранов А.И. Проблема порядка подписания внешпеэкономических сделок и публичный порядок Российской Федерации (по материалам одного из решений 
Верховното Суда России). - Московский журнал международного права, 1998, № 3.

${ }^{30}$ Достаточно вспомнитъ отношение В.И. Ленина к данному принципу и тот факт, что он был непосредственно закреплен в Конститушии СССР (пункт 10 статьи 73).

31 Лунц Л.A. Курс мехдународного частного права. Особенная часть. - М., $1975_{32}$ c. 49.

${ }_{32}$ Российская газета, 1991, 19 ноября; Ведомости Съезда народных депутатов РСФСР и Верховного Совета РСФСР, 1991, № 47, ст.1612.

33 "...установить, что на территории РСФСР до принятия соответствующих законодательньх актов РСФСР нормы бывшего Союза ССР применяются в части, не противоречащей Конституции РСФСР, законодательстөу РСФСР и настаящеку Соглашению" (Ведомости Съезда народных депутатов РСФСР и Верховного Совета РСФСР, 1991, № 51, ст.1798).

34 Пункт 1 статьи 36 “Основания для отказа в признания или приведении в исполнение арбитрахного решения" указанного Закона предусматривает: “ 1 . $B$ признании или приведении в испалнение арбитрахсного решения, независимо от того, в какой стране оно было вынесено, можст быть отказано лишь:

1) по просьбе стороны, против которой оно каправлено, если эта сторона представит компетентному суду, в котором испрашивается признание ияи приведение в исполнение, доказательства того, ито:

одна из сторон в арбитрахснаи соглашении, указанном в статье 7, была ө какой-либо мере недееспособна; или это саглашение недействительно по закону, которому стороны его подчинили, а при отсутстоии такого указания - по закону страны, где решение было вынесено; или

сторона, против которой вынесено решение, не была далхсным образак уведамлена о назначении арбитра или об арбитрахсном разбирательстве или по другим причинам не могла предстаөить сөои объяснения; или

решение өынесено по спору, не предуснотренному арбитрахскын соглашением или не подпадающеку под его условия, или содерэсит постановлекия по вопросам, вьходяцим за предель арбитрахсного соглашекия, с тем, однако, ито если постановления по ворросаи, охватываемым арбитрахсным соглашениен, могут быть отделены от тех, которые не ахөатываются такии соглашениен, то та часть арбитрахсного рещения, в которой содерхсатся постановления по вопросам, охватываемым арбитрахснын соглашением, моэсет быть признана и приведена в испалнение; или

состав третейского суда или арбитражсная процедура не соотөетствовали соглашению сторон или ө отсутстөие такового не соотөетствовали закоку той страны, где имел место арбитрахс; или решение еце не стало обязательным для сторон, или было отиенено, или его исполнение было приостаноалено судом страны, в которой или в соответстаии с законам которой оно было вынесено; либо

2) если суд найдеm, чmo:

объект спора не мозсет быть предметам арбитрахнного разбирательства по закону Российской Федерации; или

признание и приведение 6 испалнение этого арбитраэсного решения противоречат публичнаму порядку Российской Федерации".

35 Содерхащиеся в этом закпочения доводы бнли использованы в ухе упоминавшейся статъе автора "Проблема порядка подписания внешнеэкономических сделок и публичный порядок Российской Федерации (по материалам одного из решений Верховного Суда России)". - Московский хурнат мехдународного права, 1998, № 3.

${ }_{36}$ "Следует отиетить, что случаи применения оговорки о публинаи порядке к өнешнеторговым отношениям в нащей практике вообще не инели места..." (Богуславский М.М. Международное частное право. - М., 1994, с. 95). 
37 Брун М.И. Публичный порядок в международном частном праве. Петроград, 1916.

38 Пиленко A.A. Очерки по систематике частного мехдународного права. СПб, 1911.

ॐ9 Подробнее см. работу: Муранов А.И. Проблема определения суда, компетентного рассматривать вопрос о приведении в исполнение в Российской Федерации иностранных решений по коммерческим спорам. - Московский журнал международного права, 2000, № 1.

40 Пункт 14 Обзора судебной практики Верховного суда РФ "Некоторые вопросы судебной практики по грахданским делам"(Бюллетень Верховного Суда Российской Федеращии, 1998, № 9); Определение Судебной коллегин Верховного Суда РФ от 25 сентября 1998 г. "Вывод городского суда о противоречии репения Международного коммерческого арбитрахного суда при Торгово-промыпшенной палате Российской Федерации публичному порядку Российской Федеращии признан неправильным" (Извлечение) (Бюллетень Верховного Суда Российской Федерации, 1999, № 3); Постановление Президиума Верховного Суда РФ от 2 июня 1999 г. "Определение суда о разрешения принудительного исполнения на герритории Российской федерации решения Хозяйственного суда Латвии признано правильным" (Бюллетень Верховного Суда Российской Федерации, 1999, № 11).

${ }_{41}$ Например, в Определении Судебной коллегии Верховного Суда РФ от 25 сентября 1998 г. говорится, в частности: "При рассмотрении дела городской суд признал, что решение МКАС при ТПП РФ противоречит публичнаму порядку Российской Федерации, поскольку не соответствует ее законодательству.

Однако, этот өывод основан на неверном талковании понятия "публичный порядок Российской Федерации", а такхсе протиборечит содерэсанию рещения, $\theta$ которак отсутствуют ссылки на нормы мезкдународного или иностранного права. Решение арбитрахсного суда основано на нормах российского гралоданского законодательства, что вообще искаючает возмохсность ссылки на наруиение публичного порядка, поскальку применение норм национального российского права не мохет трактоваться как нарутиение публичного порядка Российской Федерации.

Содерэсание понятия "публичный порядок Российской Федерации" не совпадаем с содержсаниек национального законодательства Российской Федерации. Поскальку законодательство Российской Федерации допускает прикенение нори иностранного государства (ст.28 Закона Российской Федерации "О мезкдународном каммерческам арбитрахсе", наличие принципиального разичия мезсду российским законам и законом другого государства само по себе не моэсет бымь основанием для применения оговорки о публинни порядке. Такое применение этой оговорки означает отричание применения в Российской Федерации права иностранного государства бообще.

Под "пубалиньим порядкаи Российской Федерации" пониманотся основы общественного строд Российского государства. Оговорка о публична порядке возмохсна пищь в тех отдельных случаях, когда применение иностраннаго закона могло бы породить результат, недопустимьй с точки зрения российского провосазнания".

Статья поступила в редакцию в октибре 1999 года. 